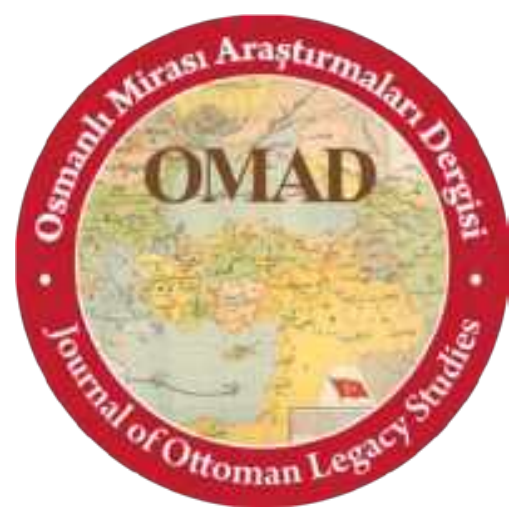

Osmanlı Mirası Araştırmaları Dergisi / Journal of Ottoman Legacy Studies

ISSN 2148-5704

www.osmanlimirasi.net

osmanlimirasi@gmail.com

Cilt 6, Sayı 14, Mart 2019 / Volume 6, Issue 14, March 2019

\title{
ERKEN CUMHURIYET DÖNEMİ SANATINDAN BİR ÖRNEK: TEKİRDAĞ ESKİ VALİ KONAĞI VE SÜSLEMELERİ
}

An E am le from the Early $e$ u lican Art: Tekirdăg ormer o ernor s Mansion and Its Ornaments

\author{
Makale Türü/Article Types : Araştırma Makalesi/Research Article \\ Geliş Tarihi/Received Date : 21.11.2018 \\ Kabul Tarihi/Accepted Date : 04.02.2019 \\ Sayfa/Pages : $49-75$ \\ DOI Numaras1/DOI Number : http://dx.doi.org/10.17822/omad.2019.111
}

\section{SEMİHA ALTIER}

(Dr. Öğr. Üyesi), Çanakkale Onsekiz Mart Üniversitesi, Fen-Edebiyat Fakültesi, Sanat Tarihi Bölümü, Çanakkale / Türkiye, e-mail: semihaaltier@hotmail.com, ORCID: https://orcid.org/0000-0001-8598-9185

\section{Atif/Citation}

Altıer, Semiha, “Erken Cumhuriyet Dönemi Sanatından Bir Örnek: Tekirdağ Eski Vali Konağı ve Süslemeleri”, Osmanlı Mirası Araştırmaları Dergisi, 6/14, 2019, s. 49-75.

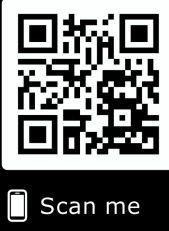



Osmanlı Mirası Araştırmaları Dergisi (OMAD), Cilt 6, Sayı 14, Mart 2019.

Journal of Ottoman Legacy Studies (JOLS), Volume 6, Issue 14, March 2019.

ISSN: $2148-5704$

\section{An Example from the Early Republican Art: Tekirdă̆ Former Governor's Mansion and Its Ornaments}

Öz: Tekirdağ Ertuğrul Mahallesi’nde günümüzde Arkeoloji ve Etnoğrafya Müzesi olarak kullanılan eski Vali Konăğ, 1927 yılında sahile hâkim bir konumda inşa edilmiştir. Yapının Latin alfabesi ile yazılı yapım ve mimar kitabelerinden, banisinin Tekirdağ'da 1926-1929 yılları arasında valilik yapan Arif Hikmet Bey, mimarının ise Kâzım Tahsin olduğu öğrenilir. Konağın cephelerindeki çiniler Kütahya'da üretilmiş; çinilerin desenleri ise Stepan Vartanyan olabileceğini savladığımız sanatçı tarafından hazırlanmıştır. Yapının inşası Cumhuriyetin kuruluşunun ilk yıllarına denk gelir ve bu dönem Türk Mimarlık tarihinde "I. Ulusal Mimari”, "Birinci Millî Üslup”, "Millî Mimari Rönesansı" "Yeni Osmanlı" ve "Yeni Klasik Üslup" gibi değişik adlarla bilinir. İstanbul ve Ankara'nın yanında Edirne, İzmir, Bursa, Kastamonu, Konya, Niğde, Balıkesir, Erzurum, Sivas, Kayseri gibi şehirlerde de en görkemli örneklerin inşa edildiği Erken Cumhuriyet Döneminde, Tekirdağ Eski Vali Konağı daha çok arazinin biçimine uydurularak, dönemin simetrik plan anlayışının dışında ancak üslubun ana prensiplerini koruyarak bir taşra örneği olarak tasarlanmıştır. Konak, cephelerindeki Kütahya çinileri ve taş süslemeleriyle şehrin en dikkat çekici ve anıtsal yapılarındandır. Boyutları, planı, cephe düzenlemesi, malzemesi, çini ve taş süslemeleriyle döneminin sosyoekonomik ve sanat anlayışını temsil eden bu yapı, I. Ulusal Mimarlık Dönemi anlayışının Tekirdağ'daki uygulaması olarak karşımıza çıkar.

Anahtar Kelimeler: Tekirdağ Vali Konağı, I. Ulusal Mimarlık Dönemi, Kütahya çinileri, Vali Arif Hikmet Bey, Mimar Kâzım Tahsin

Abstract: The former Governor's Mansion, which is being used as the Museum of Archeology and Etnography in Tekirdağ Ertuğrul Mahallesi, was built in 1927 in a location overlooking the shore. It is learned from the architectural inscriptions written in Latin alphabet that Arif Hikmet Bey, governor of Tekirdağ between 19261929 was the patron and Kazım Tahsin was the architect of the building. The tiles on the façades of the mansion were produced in Kütahya; The designs of the tiles are prepared by the artist whom we claim to be Stepan Vartanyan. The construction of the building is contemporary with the first years of the foundation of the Republic, a period named variously as "National Architecture", "First National Style", "National Architectural Renaissance", "New Ottoman" and "New Classical Style". Besides İstanbul and Ankara, the glorious examples of Early Republic Architecture can be seen in cities like Edirne, İzmir, Bursa, Kastamonu, Konya, Niğde, Balıkesir, Erzurum, Sivas, and Kayseri. Except for the symmetrical plan concept of the time, Tekirdağ Former Governor's Mansion was designed according to the main principles of the specific style but in align with the shape of the land. Thus, it could be considered as a provincial variation. This mansion is one of the most striking and monumental structures of the city with its Kütahya tiles and stone ornaments on its facades. This structure, which represents the socio-economic and artistic understanding of the era with dimensions, plan, facade arrangement, materials, tiles and stone ornaments, comes out as an application of the First National Architecture Period in Tekirdağ.

Keywords: Tekirdağ Governor Mansion, 1st National Architecture Period, Kütahya Tiles, Governor Arif Hikmet Bey, Architect Kâzım Tahsin

I. Ulusal Mimarlık Dönemi’nin mimari ve süsleme anlayışını taşrada tanımlayan Tekirdağ Eski Vali Konağı, plan özelliklerinin yanında taş süslemeleri ve Kütahya'da üretilen çinileriyle döneminin karakteristik özelliklerini sergiler (Res. 1). Bu bağlamda konak, 
Cumhuriyetin erken dönemlerinin düşünsel yapısını, inşa faaliyetlerini ve mimari süslemesini taşradaki kullanıcılarına ve seyircisine sunar. Bu çalışmada daha önce mimari ve süslemeleriyle monografik bir yayına konu olmayan Tekirdă̆ Eski Vali Konağı'nı döneminin sosyokültürel ortamı ve sanat anlayışı üzerinden değerlendirmek amaçlanmış ve özellikle usta kitabesi içermeyen yapıya, Kütahya'dan getirilen çinileri için bir sanatçı önerilmiştir.

Konağın mimari ve süsleme özelliklerine geçmeden önce yapının inşa tarihlerindeki kültür, sanat ortamından kısaca bahsetmek konunun derinleşmesi bakımından yararlı olacaktır. Osmanlı İmparatorluğu'nun (1299-1922) "Batılılaşma" olarak adlandırılan süreci öncelikle askerlik alanından başlamak üzere diğer kurumlara yayılmış; mimarlık alanında ise Barok, Rokoko, Neo-Klasizim, Oryantalizm gibi birçok Batı kaynaklı sanat üslubunun tercih edilmesine sebep olmuştur. ${ }^{1}$ Siyasi ve askerî açıdan sıkıntılı bu dönemden sonra, 20. yüzyıl başlarında Türkçülük anlayışından yola çıkarak ulusçuluğu savunan ve pek çok konuda "Millî" ve “Türkçülük” kavramını öne çıkaran Ziya Gökalp'ın (1876-1924) düşüncelerinin yayılmaya başladiğı görülür. ${ }^{2}$

Ziya Gökalp, Yusuf Akçura (1876-1935), Mehmet Emin Yurdakul (1869-1944) ve benzer görüşte olan daha pek çok düşünür ekonomi, politika, felsefe, hukuk, din ve dil alanında ulusal bilinci uyandırma ve öze dönüş gibi kavramları vurgulamış; aynı zamanda yeni anlayışla bir mimari ortamın oluşmasına da katkıda bulunmuşlardır. ${ }^{3}$ Başka bir deyişle Cumhuriyet ideolojisinin çağdaş bir ulus yaratma anlayışı çerçevesinde bütünleştirici bir mimarlık oluşturma fikri, Cumhuriyetin ilk yıllarında ulus kurma ve kimlik inşa etme amacına büyük ölçüde hizmet

\footnotetext{
${ }^{1}$ Türk mimari ve süslemesinde Batılılaşma Dönemi birçok araştırmacının dikkatini çekmiş ve pek çok yayının konusunu oluşturmuştur. Bu konuda temel yayınlar üzerinden geniş bilgi için bkz. Afife Batur, "Batılılaşma Döneminde Osmanlı Mimarlığı”, Tanzimattan Cumhuriyete Osmanlı Ansiklopedisi, C. 4, İletişim Yay., İstanbul 1986, s. 1041-1042; Ayla Ödekan, "Mimarlık ve Sanat Tarihi (1908-1980)", Türkiye Tarihi 4 Çağdaş Türkiye 1908-1980, ed. Sina Akşin, Cem Yayınevi, İstanbul 1997, s. 505-588; Doğan Kuban, Türk Barok Mimarisi Hakkında Bir Deneme, Pulhan Matbaası, İstanbul 1954; Doğan Kuban, "Türk Mimarisi'nde Barok ve Rokoko", Türk ve İslâm Sanatı Üzerine Denemeler, Arkeoloji ve Sanat Yay., İstanbul 1995, s. 131-139; Günsel Renda, "Yenileşme Döneminde Kültür ve Sanat,” Türkler, C. 15, Yeni Türkiye Stratejik Araştırma Merkezi, Ankara 2002, s. 265-283; Rüçhan Arık, Batılılaşma Dönemi Anadolu Tasvir Sanatı, Türkiye İş Bankası Yayını, Ankara 1976; Semavi Eyice, "Batı Sanat Akımlarının Değiştirdiği Osmanlı Dönemi Türk Sanatı", Türkler, C. 15, Ankara 2002, s. 285; Semavi Eyice, "XVIII. Yüzyılda Türk Sanat1 ve Türk Mimarisinde Avrupa Neoklasik Üslubu", Sanat Tarihi Yıllı̆̆gl, S. 9-10, 1981, s. 163-168. Eyice Semavi, "Batılılaşma. Mimari”, Diyanet Vakfi İslam Ansiklopedisi, C. 5, İstanbul, 1992, s. 171; Mete Tapan “Türkiye'de Uygarlık, Bayındırlık, Kentleşme ve Atatürk”, Çağdaş Düşüncenin Işı̆ğında Atatürk, Dr. Nejat F. Eczacıbaş1 Vakfi Yay., İstanbul 1983, s. 383-384, 388; Mustafa Cezar, Sanatta Batı'ya Açılış ve Osman Hamdi Bey, Erol Kerim Aksoy Kültür Eğitim Spor ve Sağlık Vakfi, İstanbul 1995.

2 Ali Cengizkan, "Birinci Ulusal Mimarlık "Savunma Hattı'nda", Modernin Saati, Mimarlar Derneği-Boyut Yay., Ankara 2002, s. 61; İlhan Tekeli, "Türkiye'de Mimarlığın Gelişiminin Toplumsal Bağlamı", Modern Türk Mimarllğgl, ed. Ahmet Evin-Renate Holod- Süha Özkan, TMMOB Mimarlar Odası Yay. Yalçın Matbaacılık, Ankara 2007, s. 18-19; Niyazi Berkes, Türkiye'de Çăgdaşlaşma, Bilgi Yayınevi, Ankara 1973, s. 354-357; Sina Akşin, “Türk Ulusçuluğu”, Cumhuriyet Dönemi Türkiye Ansiklopedisi, C. 7, İletişim Yay., İstanbul 2002, s. 19411942.

3 Abdullah Kuran, "Mimarlıkta "Yeni-Türk” Üslubu ve Osman Hamdi Bey”, Selçuklular'dan Cumhuriyet’e Türkiye'de Mimarlık, ed. Çiğdem Kafesçioğlu- Lucienne Thys-Şenocak- Timur Kuran, Türkiye İş Bankası Yay., İstanbul 2012, s. 598; Hasan Kuruyazıcı, Osmanlı'dan Cumhuriyet'e Bir Mimar Arif Hükmet Koyunoğlu, Anılar, Yazılar, Mektuplar, Belgeler, Yap1 Kredi Yay., İstanbul 2008, s. 25; İnci Nurcan Fırat, Ankara'da Cumhuriyet Dönemi Mimarisinden İki Örnek, Kültür Bakanlığı Yay., Ankara 1998, s. 2; Metin Sözen, Cumhuriyet Dönemi Türk Mimarisi, İş Bankası Kültür Yay., Ankara 1996, s. 13; Metin Sözen, Cumhuriyet Dönemi Türk Mimarlı̆ğ. Türkiye İş Bankası Kültür Yay., Ankara 1984, s. 27; Metin Sözen-Mete Tapan, 50 Yılın Türk Mimarisi, İş Bankası Kültür Yay., İstanbul 1973, 99; Nail Tan, Cumhuriyet Dönemi Kültür Çalışmalarının Dünü Bugünü Yarını, (Bir Kültür Politikası Oluşumu), BRC Basım Matbaacılık, Ankara 2003, s. 37; Orhan Cezmi Tuncer, "Mimaride Türk Milli Üslubu İlkeleri”, Mimaride Türk Milli Üslubu Semineri, İstanbul, 11-12 Haziran 1984 Bildiriler. Atatürk Kültür Merkezi Yay., İstanbul 1984, s. 68; Yıldırım Yavuz, Imparatorluktan Cumhuriyete Mimar Kemalettin, 1870-1927, Vakıflar Genel Müdürlüğü TMMOB Mimarlar Odas1, Ankara 2009, s. 11; Yıldırım Yavuz, "İkinci Meşrutiyet Döneminde Ulusal Mimari Üzerindeki Batı Etkileri”, ODTÜ Mimarlık Fakültesi Dergisi, S. 2-1, 1976, s. 13; Zeki Sönmez, Cumhuriyet Dönemi Mimarlığının Fikir Temelleri”, Cumhuriyet'in Yetmiş Beş Yılında Kültür ve Sanat Sempozyum Bildirileri. 18-19 Mart 1999, Sanat Tarihi Derneği Yay., İstanbul 2000, s. 63-74.
} 
etmiştir. ${ }^{4} \mathrm{Bu}$ bağlamda Ulusçuluk düşüncesinin yoğunlaştığı Cumhuriyet Dönemi'nde mimarlığa da duygusal / romantik yaklaşılmasına neden olmuş ${ }^{5}$ çağın kültürel ortamına uygun olarak Selçuklu ve Osmanlı mimarisinin mimari elemanları ile süsleme ögeleri başkent Ankara olmak üzere çeşitli şehirlerde inşa edilen kamu binalarında ayrıca sivil yapılarda kullanılmıştır. ${ }^{6}$

Geç Osmanlı döneminden başlayarak asıl Cumhuriyet'in ilk yıllarında etkin olan ${ }^{7}$, sınırlı sayıdaki mimarın neredeyse tümü I. Ulusal Mimarlık döneminin mimari ilkelerine bağlı kalmıştır. ${ }^{8}$ Başka bir deyişle 1920'li yılların sonlarından 1930'lu yılların başlarına kadar uygulanan $^{9}$ bu yeni mimarlık anlayışı yeni yönetimin ideallerini gerçekleştirmeyi amaçlayan

${ }^{4}$ Sibel Bozdoğan, Modernizm ve Ulusun İnşası: Erken Cumhuriyet Türkiyesinde Mimari Kültür, Çeviren: Tuncay Birkan Metis Yay., İstanbul 2002, s. 33

${ }^{5}$ Afife Batur, Vedat Tek Kimliğin İzinde Bir Mimar, Yap1 ve Kredi Yay., İstanbul 2002, s. 23; Nurcan İnci Firat, "XX. Yüzyıl Başlarında Görülen Osmanlı Mimarisi”, Türkler, C. 10, ed. Hasan Celal Güzel-Kemal Çiçek, Yeni Türkiye Yay., Ankara 1999, s. 290; İlhan Tekeli, "Mimar Kemalettin ve Eseri Hangi Ortamda Gelişti”, Mimar Kemalettin ve Çağı: Mimarlık/Toplumsal Yaşam /Politika, ed. Ali Cengizkan, TMMOB Mimarlar Odası ve Vakıflar Genel Müdürlüğü Yay., Ankara 2009, s. 38-39; Zeynep Ertuğrul, Birinci Ulusal Mimarlık Dönemi Mimarlarından Muzaffer Bey: Eserleri ve Sanat Anlayışı, Yayımlanmamış Doktora Tezi, Anadolu Üniversitesi Sosyal Bilimler Enstitüsü, Eskișehir 2007, s. 12.

${ }^{6}$ Leyla Alpagut, “1930’larda Bir Mimar: İzzet Baysal”, Edebiyat Fakültesi Dergisi, S. 26-1, Haziran 2009, s. 14-15; Mete Tapan "Türkiye'de Uygarlık, Bayındırlık, Kentleşme ve Atatürk”, Çağdaş Düşüncenin Işı̆̆ı̆nda Atatürk, Dr. Nejat F. Eczacıbaşı Vakfi Yay., İstanbul 1983, s. 388.

${ }^{7}$ Cumhuriyet döneminde etkin olacak, I. Ulusal Mimarlık dönemi ilkelerine uygun ilk mimari eserler geç Osmanlı döneminde Vedat Tek ve Kemalettin Bey'in öncülüğünde başlamıştır. Mimarların bu dönem yapıları hakkında geniş bilgi için bkz. Yıldırım Yavuz, Mimar Kemalettin ve I. Ulusal Mimarlık Dönemi, Ortadoğu Teknik Üniversitesi Yay., Ankara 1981, s. 14; Yıldırım Yavuz-Süha Özkan, "Ulusal Bir İfade Bulmak: Birinci Ulusal Üslup”, Modern Türk Mimarlı̆̆l, ed. Ahmet Evin-Renate Holod- Süha Özkan, TMMOB Mimarlar Odası Yay., Yalçın Matbaacılık, Ankara 2007, s. 45-52; Yıldırım Yavuz- Süha Özkan, "Osmanlı İmparatorluğunun Son Yılları”, Modern Türk Mimarlığı, ed. Ahmet Evin-Renate Holod- Süha Özkan, TMMOB Mimarlar Odası Yay. Yalçın Matbaacılık, Ankara 2007, s. 38-52.

8 İnci Aslanoğlu, Erken Cumhuriyet Dönemi Mimarlı̆̆ı, Bilge Kültür Sanat Yay., İstanbul 2010, s. 30; Afife Batur, "Cumhuriyet Döneminde Türk Mimarlı̆̆ı”, Cumhuriyet Dönemi Türkiye Ansiklopedisi, C. 5, Hazırlayan: Murat Belge-Seyfettin Gürsel-Mete Tunçay, İletişim Yay., İstanbul 1993, s. 1382; Metin Sözen, Cumhuriyet Dönemi Türk Mimarlığı, Türkiye İş Bankası Kültür Yay., Ankara 1984, s. 27, 35; Metin Sözen, "Birinci Ulusal Mimarlık Dönemi ve Mimarları", Mimaride Türk Milli Üslubu Semineri. Ístanbul, 11-12 Haziran 1984 Bildiriler, Atatürk Kültür Merkezi Yay., İstanbul 1984, s. 35.

${ }^{9}$ Mimar Kemaleddin Bey'in 1927'de ölümünden sonra birçok yabancı mimar Ankara'ya gelmiş, bundan sonra I Ulusal Mimarlık dönemi yerini giderek uluslararası bir anlayışa bırakmıştır. Bu konuda daha geniş bilgi için bkz. Cengiz Bektaş, "Mimarlığımızın Cumhuriyeti Cumhuriyet Dönemine Bir Bakış", Yeni Türkiye Dergisi, Cumhuriyet Özel Sayısı 4. Kültürel Değerlendirme, S. 23-24, Eylül-Aralık, 1998, s. 3069; İnci Aslanoğlu, "Birinci ve İkinci Milli Mimarlık Akımları Üzerine Düşünceler", Mimaride Türk Milli Üslubu Semineri, İstanbul, 11-12 Haziran 1984, Atatürk Kültür Merkezi Yay., İstanbul 1984, s. 42; Yıldırım Yavuz, "Yeni Bulguların Ișı̆̆ında Mimar Kemalettin ve Yapıtları", Mimar Kemalettin ve Çăğ: Mimarlık / Toplumsal Yaşam / Politika, ed. Ali Cengizkan, TMMOB Mimarlar Odası ve TC. Başbakanlık Vakıflar Genel Müdürlüğ̈ Yay., Ankara 2009, s. 140; Yıldırım Yavuz, “Tek Vedat”, Dünden Bugüne İstanbul Ansiklopedisi, C. 7, Tarih Vakfi Yurt Yay., İstanbul 1994, s. 232. Türkiye'de 1930 dan sonraki mimari faaliyetler için bkz. Afife Batur, “1925-50 Döneminde Türkiye Mimarlığı”, 75 yılda Değişen Kent ve Mimarlık, ed. Yıldız Sey-Derya Özkan, Türkiye Ekonomik ve Toplumsal Tarih Vakfi, İstanbul 1998, s. 220-228; Afife Batur, "Cumhuriyet Dönemi Mimarlığı”, Dünden Bugüne İstanbul Ansiklopedisi, C. 2, Tarih Vakfi Yurt Yay., İstanbul 1994, s. 449; İnci Aslanoğlu, "1930'lar: Türk Mimarisinde Erken Modernizm”, Cumhuriyet'in Mekânları / Zamanlan / Insanlarl, ed. Altan Elvan Ergut-Bilge İmamoğlu, Dipnot Yay., Ankara 2010, s. 25-30; İnci Aslanoğlu, Erken Cumhuriyet Dönemi Mimarlı̆̆ı, Bilge Kültür Sanat Yay., İstanbul 2010, s. 54-69; Seyfi Başkan, "Cumhuriyet Döneminde Sanat", Türkler, C. 18, ed. Hasan Celal GüzelKemal Çiçek, Yeni Türkiye Yay., Ankara 2002, 237; Sibel Bozdoğan, Modernizm ve Ulusun İnşası: Erken Cumhuriyet Türkiyesinde Mimari Kültür, Çeviren: Tuncay Birkan, Metis Yay., İstanbul 2002, 118-135; Sibel Bozdoğan, "Türk Mimari Kültüründe Modernizm: Genel Bir Bakış", Türkiye'de Modernleşme ve Ulusal Kimlik, ed. Sibel Bozdoğan, Reşat Kasaba, Tarih Vakfi Yay., İstanbul 1998, s. 121-125; Sedat Hakkı Eldem, "Elli Yillık Cumhuriyet Mimarlığı”, Mimarlık, S. 121-122, 1973, s. 6; Yıldırım Yavuz-Süha Özkan, "Ulusal Bir İfade Bulmak: Birinci Ulusal Üslup, Modern Türk Mimarlı̆ğ, ed. Ahmet Evin-Renate Holod- Süha Özkan, TMMOB Mimarlar Odası Yay., Yalçın Matbaacılık, Ankara 2007, s. 66-67. 
mimarlar tarafından desteklenmiş ve "Birinci Ulusal Mimarlık Üslubu"nun belirleyicisi olmuştur. ${ }^{10}$ Şüphesiz devletin desteği de bu dönem mimarlığını doğrudan etkilemiştir. ${ }^{11}$

“Millî Mimari”, Millî Mimari Üslubu”, Neo-Klasik Üslup”, “I. Ulusal Mimari”, “Birinci Millî Üslup", "Millî Mimari Rönesansı" "Yeni-Türk" gibi isimlerle anılan ve döneminin çağdaşlaşma anlayışını vurgulayan bu mimari anlayış, Türk Mimari ve süslemesinin geçmişe dair tasarımlarının yeniden etüt edilerek yeni çağdaş bir kimlikle ortaya konması esasına dayanır. ${ }^{12} \mathrm{Bu}$ dönem, geç Osmanlı mimarlığında Batılılaşma ile birlikte gelişen pek çok üsluba ilk tepkilerin gösterildiği, Türk mimarisinin yabancı üslup ve buna bağlı olarak yabanc1 mimarlardan uzaklaştırılması düşüncesinin egemen olduğu bir süreç olarak tanımlanmıştır. ${ }^{13}$

Gerek başkent Ankara'nın yanı sıra İstanbul, İzmir, Kastamonu, Sivas gibi büyük şehirlerde gerek taşrada kendi içinde bazı farklılıklar gösterse de bu dönem mimari ve süslemesinin temel ilkeleri belirlenmiş ve büyük oranda bu ilkelere bağlı kalınmış görünmektedir. ${ }^{14}$ Birinci Ulusal Mimarlık döneminin öncülüğünü yapan Kemalettin Bey (18701927), Vedat Tek (1873-1942) Arif Hikmet Koyunoğlu (1888-1982) ve diğer mimarlar ${ }^{15}$

${ }^{10}$ İnci Aslanoğlu, “ Cumhuriyetin İlk Yıllarında Mimari”, Türkler, C. 18, ed. Hasan Celal Güzel-Kemal Çiçek, Yeni Türkiye Yay., Ankara 2002, s. 254; Sibel Bozdoğan, Modernizm ve Ulusun İnşası: Erken Cumhuriyet Türkiyesinde Mimari Kültür, Çeviren: Tuncay Birkan, Metis Yay., İstanbul 2002, s. 31; Şeniz Çıkış, "Birinci Ulusal Mimarlık Dönemi İzmir Konutu: Yerellik ve Melezlik", METU Journal of the Faculty of Architecture, S. 28-2, 2011, s. 45; Murat Gül, "Erken Dönem Cumhuriyet Mimarisinin İmparatorluk ve Cumhuriyet Devri Çağdaşlaşma Çabalarının İlişkisi Bakımından İncelenmesi”, Cumhuriyet'in Mekânları / Zamanlan / İnsanları, ed. Altan Elvan Ergut-Bilge İmamoğlu, Dipnot Yay., Ankara, 2010, s. 286; Altan Elvan Ergut, "Sınırlar ve Sorunlar Üzerine Düşünceler Erken Cumhuriyet Dönemi ve Ulusal Mimarlık", Toplumsal Tarih Dergisi, S. 189, 2009, s. 79; Ayla Ödekan, "Mimarlık ve Sanat Tarihi (1908-1980)", Türkiye Tarihi 4 Çağdaş Türkiye 1908-1980, ed. Sina Akşin, Cem Yayınevi, İstanbul 1997, 511; Nilüfer Öndin, Cumhuriyet'in Kültür Politikast ve Sanat 1923-1950, İnsanc1l Yay., İstanbul 2003, s. 77.

${ }^{11}$ Afife Batur, "Modern Olmak: Bir Cumhuriyet Mimarlı̆̆ı Arayışı", Modern Türk Mimarlı̆̆, ed. Ahmet EvinRenate Holod- Süha Özkan, TMMOB Mimarlar Odası Yay. Yalçın Matbaacılık, Ankara 2007, s. 72.

${ }^{12}$ Afife Batur, "Milli Olarak Adlandırılan Mimari Eğilimler", Mimarlık, S. 298, 2001, s. 43; Ayla Ödekan, "Çağdan Olmak”, Cumhuriyet'in Renkleri, Biçimleri, ed. Ayla Ödekan, Tarih Vakfi Yay., İstanbul 1999, s. 4; İnci Aslanoğlu, "Modernizmin Başlangıç Aşamasında 1926/33 Yılları Arası Türk Mimarlığında Yaşanan Gelişmelerin Bir Değerlendirmesi”, Prof. Doğan Kuban'a Armağan, ed. Zeynep Ahunbay- Deniz Mazlum, Eren Yay., İstanbul 1996, s. 17; İnci Aslanoğlu, "Birinci ve İkinci Milli Mimarlık Akımları Üzerine Düşünceler”, Mimaride Türk Milli Üslubu Seminer, İstanbul 11-12 Haziran 1984, Atatürk Kültür Merkezi Yay., İstanbul 1984, s. 41; Metin Sözen, Cumhuriyet Dönemi Türk Mimarisi, İş Bankası Kültür Yay., Ankara 1996, s. 13; Metin Sözen, Cumhuriyet Dönemi Türk Mimarlı̆̆l, Türkiye İş Bankası Kültür Yay.., Ankara 1984, s. 30; Metin Sözen, "Birinci Ulusal Mimarlık Dönemi ve Mimarları”, Mimaride Türk Milli Üslubu Semineri, İstanbul 11-12 Haziran 1984 Bildiriler, Atatürk Kültür Merkezi Yay., İstanbul 1984, s. 36; Zeki Sönmez, "Cumhuriyet Dönemi Mimarllğının Fikir Temelleri”, Cumhuriyet'in Yetmiş Beş Yılında Kültür ve Sanat Sempozyum Bildirileri, 18-19 Mart 1999, Sanat Tarihi Derneği Yay., İstanbul 2000, s. 65

13 Üstün Alsaç, Türkiye’deki Mimarlık Düşüncesinin Cumhuriyet Dönemindeki Evrimi, Karadeniz Teknik Üniversitesi Bask1 Atelyesi, Trabzon 1976, 19-20; Y1ldırım Yavuz, Mimar Kemalettin ve I. Ulusal Mimarlık Dönemi, Ortadoğu Teknik Üniversitesi Yay., Ankara 1981, s. 21; Yıldırım Yavuz, "Mimar Kemalettin Bey (18701927)”, ODTÜ Mimarlık Fakültesi Dergisi, S. 7-1, 1981, s. 62; Yıldırım Yavuz-Süha Özkan, "Osmanlı Mimarlığının Son Yılları”, Tanzimattan Cumhuriyete Türkiye Ansiklopedisi, C. 4, İletişim Yay., İstanbul 1985, s. 1080-1081; Zeki Sayar, "Mimarlığımı: 1923-1950”, Mimarlık, S. 2, 1973, s. 20.

${ }^{14} \mathrm{Bu}$ mimari ilkeler, uygulandığı yapılar ve mimarları ile ilgili daha geniş bilgi için bkz. İnci Aslanoğlu, "1930'lar: Türk Mimarisinde Erken Modemizm”, Cumhuriyet'in Mekânları / Zamanlan / Insanları, ed. Altan Elvan ErgutBilge İmamoğlu, Dipnot Yay., Ankara 2010, s. 31-46; İnci Nurcan Firat, Ankara'da Cumhuriyet Dönemi Mimarisinden İki Örnek, Kültür Bakanlığı Yay., Ankara 1998, s. 2; Zeynep Ertuğrul, Birinci Ulusal Mimarlık Dönemi Mimarlarından Muzaffer Bey: Eserleri ve Sanat Anlayışı, Yayımlanmamış Doktora Tezi, Anadolu Üniversitesi Sosyal Bilimler Enstitüsü, Eskişehir 2007, s. 9-19.

${ }^{15}$ I. Ulusal Mimarlık döneminin esas temsilcileri olan Kemalettin Bey, Vedat Tek ve Arif Hikmet Koyunoğlu dışında diğer mimarlar arasında Ahmet Burhanettin Tamc1, A. Kemal, Ahmet Kemalettin, Alaeddin Özaktaş, Ali Talat, Aram Hanciyan, Cemil, Ekrem Hakkı Ayverdi, Falih Ülkü, Galip, Gulio Mongeri, Hafi, İbrahim Beykozoğlu, İrfan, J. D’Armi, Kavafyan, Kiryadikis, Küçük Kemal, Kemal Altan, Leon Güreğyan, M. D. Çurvidas, Mehmet Fesçi, Mesut Özok, Mehmet Nihat Nigizberk, Mukbil Kemal, Muzaffer, Nafilyan, Necmettin Emre, Nesim Sisa, Nuri Nafiz, Pappa, Peçilas, Rafael Rus, Şefik, Tahsin Sermet, Tanaş Yamas, Taşçıan, U. Ferrari, Yahya Ahmet, Vangel, Yorgiadis, Ziya, Zühtü Başar vardır. Bu konuda geniş bilgi için bkz. Ayla Ödekan "Mimarlık ve Sanat Tarihi (1908-1980)”, Türkiye Tarihi 4 Çă̆daş Türkiye 1908-1980, ed. Sina Akşin, Cem Yayınevi, İstanbul 1997, s. 
aldıkları eğitimin de yol göstericiliğinde geçmişteki mimarlık ürünlerini incelemiş ve tasarımlarında bunlardan yararlanmışlardır. ${ }^{16}$ Çünkü bu mimarlara göre, Türk sanatında bir Rönesans yaratabilmek için, eski ustalar tarafından yapılmış olan eserleri örnek almak gerekliydi. ${ }^{17} \mathrm{Bu}$ düşünceden hareketle erken Cumhuriyet döneminde "Millî karakter" taşıyan yapılar inşa edilmiştir. ${ }^{18}$

$\mathrm{Bu}$ ulusal sanat yaratma anlayışı geleneksel biçimlere bağl1, cephe süslemelerine yoğunlaşan seçmeci bir cephe mimarlığı olarak da görülmüştür. Başka bir deyişle bu mimarlar cephe tasarımına büyük önem vermişler ve plan tasarımından öte, cepheyi odak noktası seçmişlerdir. Selçuklu ve Osmanlı dönemlerinde kullanılmış farklı biçimlerdeki kemerleri, özellikle katları birbirinden ayıran silmeler veya taş kabartma yatay panoları, kendi içinde simetrik bir anlayışla düzenlenen ve her katta değişik pencere biçimleri yapılarda kullanılmıştır. $\mathrm{Bu}$ şekilde cephelerde bir hareket yaratarak yeni düzenlemeler uygulamışlardır. Ayrıca bu dönem sanatçıları, yine Selçuklu ve Osmanlı dönemlerinin taş ve çini motif / kompozisyonlarını yeniden ele almışlardır. Kütahya'daki atölyelere sipariş edilen çiniler yapıların içlerine, daha çok da dış cephelerine yerleştirilmiştir. ${ }^{19} \mathrm{Bu}$ hâliyle Birinci Ulusal Mimarlık Dönemi bazı araştırmacılar tarafından; yeni teknolojiye ayak uydurmaktan ve çağın gereksinimlerine yanıt vermekten uzak, seçmeci, biçimsel, duygusal ve akademik bir akım olarak tanımlanmıştır. ${ }^{20}$

Ulusal Mimarlık Dönemi ilkelerine uygun yapılaşma etkinlikleri Cumhuriyet'in başkenti Ankara'da başlamak ve yoğunlaşmakla birlikte, bu dönemin başkent dişında gerçekleştirilen mimarlık örnekleri de, Türk mimarlık tarihini çeşitlendiren ve zenginleştiren ilginç veriler ortaya koymuştur. ${ }^{21}$ Geç Osmanlı döneminde belirmeye başlayan yeni yapı türleri erken Cumhuriyet Dönemi'nde de devam etmiş; nitekim 1920'li yıllarda başkent dışındaki Edirne, İzmir, Bursa, Kastamonu, Konya, Niğde, Balıkesir, Erzurum, Sivas, Kayseri gibi şehirlerde özellikle hükûmet binas1, banka, otel, tren istasyonu, okul, postane, karakol gibi kamu yapıları dönemin ulusal mimari anlayışına uygun olarak inşa edilmiştir. ${ }^{22}$

Farklı ihtiyaçlara cevap veren yeni yapı türlerinin belirdiği geç Osmanlı döneminden itibaren, Erken Cumhuriyet döneminde de süregelen yapı türleri arasında vali konakları hem sivil hem de idari yapılar olması bakımından önemlidir. Osmanlı döneminden itibaren hükûmet

525-526; Üstün Alsaç, “Türkiye Mimarlık Düşüncesinin Cumhuriyet Dönemindeki Evrimi”, Mimarlık Dergisi, S. 11-12 (121), 1973, s. 13; Metin Sözen, Cumhuriyet Dönemi Türk Mimarisi, İş Bankası Kültür Yay., Ankara 1996, s. 21; Metin Sözen, Cumhuriyet Dönemi Türk Mimarlı̆̆ , Türkiye İş Bankası Kültür Yay., Ankara 1984, s. 33; Metin Sözen, "Birinci Ulusal Mimarlık Dönemi ve Mimarları", Mimaride Türk Milli Üslubu Semineri, İstanbul 1112 Haziran 1984 Bildiriler, Atatürk Kültür Merkezi Yay., İstanbul 1984, s. 38; Nail Tan, Cumhuriyet Dönemi Kültür Çalışmalarının Dünü Bugünü Yarını, (Bir Kültür Politikası Oluşumu). BRC Basım Matbaacılık, Ankara 2003, s. 37-38; Yıldırım Yavuz, Imparatorluktan Cumhuriyete Mimar Kemalettin, 1870-1927, Vakıflar Genel Müdürlüğü TMMOB Mimarlar Odas1, Ankara 2009, s. 15.

${ }^{16}$ Üstün Alsaç, "Türkiye Mimarlık Düşüncesinin Cumhuriyet Dönemindeki Evrimi”, Mimarlık Dergisi, S. 11-12 (121), 1973, s. 14.

${ }^{17}$ Celal Esad Arseven, Türk Sanatı, Cem Yayınevi, İstanbul 1984, s. 181-182

${ }^{18}$ Hamit Kemalî Söylemezoğlu, “ Mimarlığımız: 1923-1950”, Mimarlık, S. 2, 1973, s. 25.

${ }^{19}$ Metin Sözen-Mete Tapan, 50 Yılın Türk Mimarisi, İş Bankası Kültür Yay., İstanbul 1973, s. 105.

${ }^{20}$ Cengiz Bektaş, "Mimarlığımızın Cumhuriyeti Cumhuriyet Dönemine Bir Bakış”, Ege Mimarlık Dergisi, S. 30, s. 1999, s. 28; Doğan Hasol, Ansiklopedik Mimarlık Sözlüğü, Yapı Endüstri Merkezi, İstanbul 1998, s. 465-466; İnci Aslanoğlu, Erken Cumhuriyet Dönemi Mimarlı̆̆l, Bilge Kültür Sanat Yay., İstanbul 2010, s. 30; Zeynep Ertuğrul, Birinci Ulusal Mimarlık Dönemi Mimarlarından Muzaffer Bey: Eserleri ve Sanat Anlayışı, Yayımlanmamış Doktora Tezi, Anadolu Üniversitesi Sosyal Bilimler Enstitüsü, Eskişehir 2007, s. 13-15.

${ }^{21}$ Leyla Alpagut, “1930’larda Bir Mimar: İzzet Baysal”, Edebiyat Fakültesi Dergisi, S. 26-1, Haziran 2009, s. 14.

${ }^{22}$ İnci Aslanoğlu, “ Cumhuriyetin İlk Yıllarında Mimari”, Türkler, C. 18, ed. Hasan Celal Güzel-Kemal Çiçek, Yeni Türkiye Yay., Ankara 2002, s. 255; Sibel Bozdoğan, Modernizm ve Ulusun İnşası: Erken Cumhuriyet Türkiyesinde Mimari Kültür, Çeviren: Tuncay Birkan Metis Yay., İstanbul 2002, s. 54; Üstün Alsaç, "Türkiye Mimarlık Düşüncesinin Cumhuriyet Dönemindeki Evrimi”, Mimarlık Dergisi, S. 11-12 (121), 1973, s. 13; Zeynep Ertuğrul, Birinci Ulusal Mimarlık Dönemi Mimarlarından Muzaffer Bey: Eserleri ve Sanat Anlayışı, Yayımlanmamış Doktora Tezi, Anadolu Üniversitesi Sosyal Bilimler Enstitüsü, Eskişehir 2007, s. 13. 
nezdinde eyaletlerin birincil sorumlusu valiler olmuştur. ${ }^{23}$ Valiler resmî işleri yürüttükleri, aynı zamanda kapı halkının bir kısmını da barındıran gösterişli konaklarda ikamet etmişlerdir. Bu konakların bir kısmı vali için kiralanmış veya inşa ettirilmiştir. ${ }^{24}$ Bu konakların masraflarının da halk tarafından karşılandığı bilinmektedir. Şehir ileri gelenlerinin özendikleri bir yaşam biçiminin geçtiği bu konaklar başkent İstanbul' daki sadrazam konaklarının taşradaki benzerleri olarak düşünmüştür. ${ }^{25}$

Tanzimat Dönemi’yle (1839-1876) birlikte modern kent düzenlemeleri yap1lırken bir hükûmet meydanı olușturulmuş ve bu meydanının en önemli yapısı hükûmet konakları olmuştur. ${ }^{26}$ Başka bir deyişle bu dönemde sivil bürokraside ortaya çıkan yeni yapılanma birçok sancak merkezinde birbirine işlevsel ve mekânsal olarak benzeyen tasarımların ortaya çıkmasına neden olmuştur. ${ }^{27}$

Hükûmet konakları devletin otoritesini temsil ederek halkta, saygı ve bağlılık oluşturması da amaçlanarak anıtsal ve vakur bir tarzda, döneminin kültür seviyesine uygun bir mimari anlayışla yapılmışlardır. ${ }^{28} \mathrm{Bu}$ yapılarda, bir yandan yerellik diğer yandan devlet otoritesini yansitacak simgesellik bir aradadır. ${ }^{29}$

Cumhuriyet'in ilk yıllarında daha çok Tanzimat Dönemi'nde yapılan eski hükûmet konakları kullanılmıştır. 1930'lardan itibaren 1940'lara kadar az sayıda yeni hükûmet konağının yapıldığı bilinmektedir. ${ }^{30}$ Aşağıda ayrıntılı olarak ele alacağımız Eski Vali Konağı da Cumhuriyetin ilanından sonra başkent dışında idari işleri yönetmek üzere Tekirdağ'da inşa edilen bir yapıdır.

Tekirdağ, Osmanlı döneminde Trakya'da üretilen ürünlerin deniz yoluyla İstanbul'a sevk edilmesinde önemli bir liman şehri olmuştur. ${ }^{31}$ Şehrin aynı zamanda Osmanlıların iki önemli devlet merkezi olan İstanbul ve Edirne arasında konumlanmas1, Tekirdağ'1 seferlere giden sultanların uğrak yeri hâline getirmiştir. ${ }^{32}$ Ancak şehir bu konumunu Balkan Savaşları, I. Dünya Savaşı ve Kurtuluş Savaşı yıllarındaki sıkıntılı günlerde yitirmiştir. ${ }^{33}$ Edirne vilayeti içinde bir sancak merkezi olan şehir, Cumhuriyet'in ilanından kısa bir süre sonra 1927 yılında vilayet merkezi durumuna getirilir. ${ }^{34}$ Tekirda ğ’ın vilayet merkezi olmasıyla birlikte resmî işlerin

${ }^{23}$ Musa Çadırcı, Tanzimat Döneminde Anadolu Kentlerinin Sosyal ve Ekonomik Yapıları. Türk Tarih Kurumu Yay., Ankara 1991, s. 17-18, 20.

24 İlber Ortaylı, "Söyleşi: Osmanlı'dan Bugüne Hükümet Konakları”, Mimarlık, S. 203, 1984, s. 3.

${ }^{25}$ Musa Çadırcı, age., s. 21.

${ }^{26}$ İlber Ortaylı, agm., 4-5. Hükümet konakları konusunda sanat tarihi bakımından en ayrıntılı çalışmalar, Nurcan Yazıcı tarafından yapılmıştır. Araştırmacının bu konudaki Yay. için bkz. Nurcan Yazıcı, "Trabzon Örneğinde Tanzimat'tan Cumhuriyet'e Hükümet Konağı Binaları", Uluslararası Sosyal Araştırmalar Dergisi, S. 1-5, 2008, s. 943-959; Nurcan Yazıc1, "Amasya'daki Hükümet Konağı Binaları”, Sanat Dergisi, Atatürk Üniversitesi Güzel Sanatlar Fakültesi Dergisi, S. 18, 2010, s. 91-105.

27 Sevgi Aktüre, “Osmanlı Devleti'nde Taşra Kentlerindeki Değişimler”, Tanzimat’tan Cumhuriyet'e Türkiye Ansiklopedisi, C. 4, İletişim Yay., İstanbul 1985, s. 896.

${ }^{28}$ Abidin Mortaş, "Hükümet Konakları", Arkitekt, S. 11-12, 1944, s. 251

${ }^{29}$ Yasemin Sayar, "Türkiye'de Modernleşme ve Milliyetçilik: Milli Kimlik Sorunu ve Mimari İfadesi”, Mimarlık, S. 291, 2000, s. 52.

${ }^{30}$ İnci Aslanoğlu, "Söyleși: Osmanlı’dan Bugüne Hükümet Konakları”, Mimarlık, S. 203, 1984, s. 6.

${ }^{31}$ Besim Darkot, "Tekirdağ", MEB İslam Ansiklopedisi, C. 12/1, MEB Devlet Kitapları, Eskişehir 2001, s. 134; Necmettin Aygün, "XIX Yüzyıl Başlarında İstanbul Merkezli Osmanlı Deniz Taşımacılığı", OTAM, S. 23, Bahar, 2008, s. 53-84; Murat Yıldız- Nuran Koltuk, Arşiv Belgelerine Göre XVII-XX. Yüzyıllarda Tekirdağ'da Ekonomik Hayat, Kitapevi, İstanbul, 2016, s. XIII; P. L. İnciciyan, - Hrand D. Andreasyan, "Osmanlı Rumelisi'nin Tarihi ve Coğrafyası”, Güneydoğu Avrupa Araştırmaları Dergisi, S. 4-5, İstanbul, 1976, s. 136; Süreyya Faroqhi, Osmanlı Şehirleri ve Kırsal Hayatı, Çeviren: E. S. Özcan, Doğubatı Yay., Ankara 2006, s. 139-153; Ümit Ekin- Hümmet Kanal, “Tekfurdağı Sancağı'nın Sosyal ve Ekonomik Yapısı (1890-1902)”, HUMANITAS, S. 4, 2014, s. 215.

${ }^{32}$ Pars Tuğlacı, Osmanlı Şehirleri, Milliyet Yay., İstanbul 1985, s. 281.

${ }^{33}$ Hacer Ateş, "Tekirdağ”, Diyanet Vakfi İslam Ansiklopedisi, C. 40, İstanbul 2011, s. 362.

34 Doğan Kınık, "Tekirdağ", Eczacıbaşı Sanat Ansiklopedisi, C. 3, Yem Yay., İstanbul 1997, s. 1756; Mehmet Tuncel, “Türkiye'de Kıyı Taraçaları Üzerinde Kurulan Şehirler: Tekirdağ Örneği”, Rodos'tan Süleymanpaşa'ya Tekirdă̆, Uluslararası Tekirdă̆ Tarihi Sempozyumu Bildirileri, Tekirdağ 26-27 Mart 2015 Namık Kemal 
yönetildiği bir konağa ihtiyaç kendiliğinden doğmuş ve bu dönemin yarattığı sanat üslubu çerçevesinde biçimlendirilmiştir. 72 pafta, 294 ada ve 4 parsele kayıtlı konağın ${ }^{35}$ taştan yapıllmış bir Ermeni kilisesi olan St. Perguitsch'in yerine inşa edildiği söylenir. ${ }^{36}$

Sahile hâkim bir konumda inşa edilen Eski Vali Konağı'nın (Res. 2) banisi, mimarı ve yapım tarihi kitabelerinden tespit edilebilmektedir.

Konağın Barbaros Caddesi'ne bakan ana giriş kapısı üzerinde, saçak altına yerleştirilen Latin alfabesi ile yazılı iki satırlık, yatay dikdörtgen çini kitabeden banisinin Tekirdağ'da 19261929 yıllarında Cumhuriyet döneminin 3. valisi ${ }^{37}$ Arif Hikmet Bey olduğu öğrenilir (Res. 3).

Kitabede "Tekirdağ Vali Konağı 1927 senesinde Vali Arif Hikmet Bey tarafından inşa itdirilmiştir" ibaresi yer alır. Kapının sağında, Latin alfabesi ile iki satırlık çini dikdörtgen bir pano içinde ise "Mimar Kâzım Tahsin"in adı yazar (Res. 4).

Yapı 1977 yılında İl Özel İdaresinden satın alınarak Müze Müdürlüğüne tahsis edilmiş ve hâlen müze binası olarak kullanılmaktadır. ${ }^{38}$

Valilik binası, inşa edildiği tarihten günümüze çeşitli iç ve dış tamiratlar geçirmiştir. Yapının en kapsamlı tadilatı 1973 yılı sonlarında başlamış; onarım sonrasında ancak 1983 yılında, Müze'nin teşhir ve tanzim işlerine geçilebilmiştir. ${ }^{39} \mathrm{Bu}$ tamiratın belgeleri ve fotoğrafları kayıt altına alınmış ve bugün Müze Müdürlüğünün arşivinde saklanmaktadır. Yapı günümüzde, kullanım amacı da göz önünde bulundurulursa iyi durumdadır.

Kuzey-güney doğrultusunda uzanan konak düzgün olmayan dikdörtgen planlıdır. Yapı, dönemin simetrik plan uygulamasının dıșına çıkılarak arazinin biçimine uygun șekilde, yükseltilmiş bodrum kat ile birlikte iki kat olarak tasarlanmıştır (Res. 5). Birinci ve ikinci kat arasında bir de asma kat bulunmaktadır. Arazinin kot farkından ve cephe tasarımından dolayı caddeye bakan batı ve kuzeybatı cephe iki, bahçe ve sahile bakan doğu cephe dört, Namık Kemal İlkokuluna bakan kuzey cephe ve kısmen caddeye bakan güney cephe üç kat görüntüsü verir.

Bodrum ve birinci kat L biçimli bir giriş holünün üç yanına sıralanmış odalardan müteşekkildir. Giriș ve üst kat mekânları bugün müzenin idari birimleri ve teşhir salonu olarak hizmet verirken, alt kat servis mekânları olarak kullanılmaktadır. En üst kat ise merkezde büyük bir salonun etrafına sıralanmış odalardan oluşmakla birlikte sergi salonu kullanımına uygun bir şekilde bölümlendirilmiştir.

Bu dönem mimarisi cephe tasarımına büyük önem verdiğinden, bu özelliği konakta da görmek mümkündür. Cephelerin tümünde geleneksel Türk mimarisinin özellikle de konutlarının cephe tasarım anlayışından izlere rastlanmaktadır. Girişi vurgulayan anıtsal portal anlayışı, köşelerde kule izlenimi veren cepheli çıkıntılar, cumba izlenimi veren cepheden taşkın birimler, geniş saçaklar bunlardan birkaçıdır.

Konağın kuzey cephesi dışında tüm cepheleri, özellikle de Barbaros Caddesi'ne bakan kuzeybatıdaki ana giriş cephesi yoğun bir şekilde Kütahya çinileriyle renklendirilmiş; öte yandan taş süslemeli panellerle de hareketlendirilmiştir. Dikdörtgen iki kanatlı sonradan üzeri

Üniversitesi, ed. Mehmet Y1ldı, Kitabevi, İstanbul 2016, s. 64; Mehmet Tuncel, “Tekirdağ (Bugünkü Tekirdağ)”, Diyanet Vakfi İslam Ansiklopedisi, C. 40, İstanbul 2011, s. 362.

${ }^{35}$ Anonim, Kültür Envanteri, Tekirdağ Belediye Başkanlığı, Tekirdağ 2007, s. 54.

${ }^{36}$ Hikmet Çevik, Tekirdağ Tarihi Araştırmaları, Ahmet Sait Basımevi, İstanbul 1949, s. 80.

${ }^{37}$ Mehmet Serez, Tekirdağ Tarihi ve Coğrafyası Araştırmaları, Dönmez Ofset, Ankara 2007, s. 40.

${ }^{38}$ Hasan Akarsu, Tekirdağ Sonsuz Gurbet, Heyamola Yay., İstanbul 2010, s. 113; Nazif Toybıyık- Mustafa Özkabak vd., Tekirdă̆ Marmara'nın İncisi, Tekirdağ Valiliği Yay., Tekirdağ 1992, s. 25; Mehmet Akif Ișın -Mehmet Serez vd., Yaşayan Tekirdă̆, Hazırlayan: Sezai Kurt, TC Tekirdağ Valiliği Yay., İstanbul 2003, s. 113.

39 1978-1979 yılında yoğunlaşan bu çalışmalar sırasında konağın büyük ölçüde, neredeyse yeniden inşa edilir gibi tamirat geçirdiği ilgili kurumlar arasındaki yazışmalardan ve fotoğraflardan anlaşılır. 
boyanmış bronz ana giriş kapısının üzerinde konsolların taşıdığı küçük bir balkon yer alır ve bu balkona sivri kemerli bir kapı açılır (Res. 1). Yapının bu cephesi diğerleri gibi, döneminin tipik süsleme karakterini yansitır.

Batı cephe, güney kısmından girişi vurgulamak üzere ana yapıdan dışarı taşkındır (Res. 6). Altta sekiz dikdörtgen, üstte altısı sivri kemerli; biri dikdörtgen yedi pencere yer alır. Pencereler, dolayısıyla iki kat arası çini ve taş süsleme panelleriyle birbirinden ayrılmıştır. Alt kat pencereleri dış etkenlerden korunmak için demir kafeslidir.

Arka ve yan cepheler nispeten daha sade tasarlanmıştır. Kuzey cephe diğerlerine göre en sade tasarımı olan alandır (Res. 7). Bu cephede bodrum katta dikdörtgen bir kapı yer alır. Alt ve üst katta simetrik şekilde yerleştirilmiş dikdörtgen pencereler cepheyi hareketlendiren yegâne unsurlardır.

Doğu cephe, yapının bahçesine açılarak buradan sahile bakmaktadır. Cephenin sağ kısmı giriş katın üzerinde yükselen teraslı bir balkon (Res. 8), sol kısmı ise ana yapıdan dışa çıkmalı bir birim olarak planlanmıştır (Res. 9).

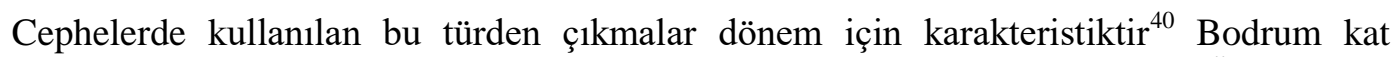
dikdörtgen iki kapının iki yanında dikdörtgen pencere açıklığı ile tasarlanmıştır. Üst katların pencereleri de yan yana üçer sıra hâlinde simetrik şekilde açılmışlardır. Sol kısım giriş katın cephesinde küçük dikdörtgen bir pencere üst katın balkonunun altında tasarlanmıştır. Balkona açılan büyük kareye yakın dikdörtgen kapı-pencerenin üzerinde yuvarlak kemerli bir pencere bulunur. Güney cephenin (Res. 10) merkezinden, 12 basamaklı bir merdivenle ulaşılan dikdörtgen bir kapıyla, giriş katına çıkılır (Res. 11).

Kapının üzerinde sivri kemerli bir pencere bulunur. Kapının sağındaki birim dışarıya üç cepheli, sol kısmındaki birim ise dikdörtgen şekilde taşarak inşa edilmiştir. Sağdaki üç cepheli birimin her yüzünde birer olmak üzere; bodrum katta dikdörtgen biçimli üç, üzerinde sivri kemerli üç, en üst katta ise küçük bir balkona açılan sivri kemerli ikiz pencere uygulaması görülür.

Sol birimde ise, bodrum katta küçük ve yatay dikdörtgen pencere açıklı̆̆ı dikkat çeker. Giriş katına denk gelen katta, her yüzeyde birer dikey dikdörtgen ve en üst katta yine her yüzeyde birer sivri kemerli pencere bulunur. Bu birimin hemen yanında mimarın kitabesinin olduğu kısım bulunur ve sonradan kapatıldığg anlaşılan giriş kata denk gelen bir dikdörtgen ve üst katta sivri kemerli bir pencere yer alır.

Yapının kırma çatısı Marsilya tipi kiremitle kaplı ve geniş saçaklıdır. Saçakları destekleyen herhangi bir sistem yoktur.

Yapının inşa malzemesi söz konusu olduğunda, duvarlarında kesme taş ve tuğla kullanıldığı görülür. Kesme taş üzerine kalın sıva yapılmış ve boyanmıştır.

Konaktaki taş, maden ve çini süslemeleri de döneminin süsleme anlayışını tanımlayan bir anlayışı sergiler. Erken Cumhuriyet Dönemi'nin bezeme beğenisini seyircisine sunan Eski Vali Konağı'nın en çarpıcı süslemeleri başta çini ve taş malzemenin kullanıldığı giriş ve caddeye kısmen bakan diğer yan cephelerde toplanmıştır. Yapının ana süsleme ögesi olan çiniler, bu dönemin özelliği olarak Kütahya'daki atölyelerde hazırlanmıştır. Kütahya eski bir yerleşim olmasından dolayı daha ilk çağlardan itibaren şehirde üretim başlamış; bu seramik ve çiniler zaman içinde farklı uygarlıkların, renk, biçim, teknikleriyle kesintisiz günümüze dek devam

\footnotetext{
${ }^{40}$ Metin Sözen, Cumhuriyet Dönemi Türk Mimarlı̆̆l, Türkiye İş Bankası Kültür Yay., Ankara 1984, s. 31; Metin Sözen, "Birinci Ulusal Mimarlık Dönemi ve Mimarları", Mimaride Türk Milli Üslubu Semineri, İstanbul, 11-12 Haziran 1984 Bildiriler, Atatürk Kültür Merkezi Yay., İstanbul 1984, s. 37; Seyfi Başkan, "Türk Modernleşmesi ve Erken Cumhuriyet Döneminin 'Milli Mimarlığı'”, Turkish Studies International Periodical for the Languages, Literature and History, S. 11/13, 2016, s. 110.
} 
ettirmiştir. ${ }^{41}$ Türk-İslam dönemi söz konusu olduğunda Kütahya'daki ilk Osmanlı çinileri ile ilgili bilgiler tartışmalıdır. Ancak bugün en erken Osmanlı dönemi çinileri ile süslenmiş 1377 tarihli Kurşunlu Cami minaresindeki tek renk sırlı tuğlalar ilk örneklerden kabul edilir. ${ }^{42} \mathrm{Bu}$ tarihten sonra Kütahya'da çini üretimi farklı atölyelerde çalışan ustalarca geliştirilmiş teknikler, biçimler, motif-kompozisyonlarla günümüze kadar devam etmiştir. ${ }^{43}$ Osmanlı döneminde önemli bir çini merkezi olan İznik'le karşılaştırıldığında sarayın etkisinden biraz daha uzak kalan Kütahya'da çini sanatı farklı bir yoldan gelişerek bu sanat kolu halkın temel geçim kaynaklarından olmuştur. ${ }^{44}$ Başka bir deyişle İznik, saray ve çevresi için çini ve seramik üretimini karşılamış; Kütahyalı çini ve seramik ustaları ise, daha çok Anadolu halkı için üretim yapmıştır. Bu durum Kütahya çinilerinin hâlâ üretiliyor olmasının temel sebeplerinden biri olarak görülmektedir. ${ }^{45}$

19. yüzyıl sonu 20. yüzyıl başında Osmanlı piyasasına giren ithal üretimler nedeniyle Kütahya'da çini ve seramik alanında bir durgunluk hatta gerileme söz konusu olsa da Cumhuriyet Dönemi Kütahya'sında I. Ulusal Mimarlık Dönemi bağlamında yeniden bir canlanma yaşanmıştır. ${ }^{46}$ Kütahya çinileri 16 . yüzyıl klasik dönem Osmanlı çinilerinin İznik merkezli çini tasarımlarının çok benzerleridir ve neredeyse bazı tasarımlar bire bir kopyalanmıştır. Bunlar arasında yaprak sayıları değişebilen çiçekler, karanfil, palmet, lotus, rumi, kıvrık dallar, hançer yapraklar, hatayilerden oluşan kompozisyonlar dikkat çeker. ${ }^{47}$ Literatüre "Şam İşi”" olarak geçmiş Osmanlı çini grubunu taklit eden bu çinilerin düşük kaliteli oldukları düşünülür. ${ }^{48}$

${ }^{41}$ Kütahya'da ilk Tunç'tan başlayarak Bizans dönemine kadarki İslam öncesi süreçte gelişen seramik sanatı hakkında geniş bilgi için bkz. Arif Hikmet Koyunoğlu, "Türk Mimarisinde Çini Sanatı ve Bezemeleri”, Mimarlık, S. 7, 1984, s. 11; Hülya Bilgi, "İslam Öncesi Kütahya Yöresi Seramik Sanatı”, Toprak, Ateş, Sir, Tarihsel Gelişimi Atölyeleri ve Ustalarıyla Kütahya Çini ve Seramikler, Hazırlayan: Garo Kürkman, Suna ve İnan Kıraç Vakfi Yay., İstanbul 2005, s. 15-29; Rıfat Çini, Türk Çiniciliğinde Kütahya, Uycan Yay., İstanbul 1991, s. 19; Rıfat Çini, Kütahya in Turkish Tile Making, Uycan Yay., İstanbul 1991, s. 19.

${ }^{42} \mathrm{Bu}$ tartışmalarla ilgili geniş bilgi için bkz. Belgin Demirsar Arlı, "Kütahya Çiniciliği”, Anadolu'da Türk Devri Çini ve Seramik Sanatı, ed. Gönül Öney-Zehra Çobanlı, Kültür ve Turizm Bakanlığı, İstanbul 2007, s. 331.

${ }^{43} \mathrm{Bu}$ gelişimle ilgili geniş bilgi için bkz. Mustafa Kızıl, Cumhuriyet Dönemi Kütahya Çinisinde Görülen Uygulama Teknikleri ve Yenilikler, Yayımlanmamış Yüksek Lisans Tezi, Kocatepe Üniversitesi Sosyal Bilimler Enstitüsü, Afyon 2010, s. 5; Ebru Köse, Sadberk Hanım Müzesi Teşhirindeki Sinırlı Sayıda Kütahya Çini Koleksiyonunun Belgelenmesi, Yayımlanmamış Yüksek Lisans Tezi, Gazi Üniversitesi Eğitim Bilimleri Enstitüsü, Ankara 2014, s. 23-27; Gönül Öney, İslâm Mimarisinde Çini. Ada Yay., İstanbul 1987, s. 73; Oktay Aslanapa, "Kütahya Keramik Sanatı”, Atatürk'ün. Doğumunun 100. Yılına Armăgan, İstanbul Üniversitesi Edebiyat Fakültesi Yay., İstanbul 1981-1982, s. 141; Oktay Aslanapa, Osmanlılar Devrinde Kütahya Çinileri, İstanbul Üniversitesi Edebiyat Fakültesi Yay., Üçler Basımevi, İstanbul 1949, s. 44-78.

${ }^{44}$ Güner Sümer, “Kütahya Çinisi ve Günümüzdeki Durumu”, Türkiye’de El Sanatları Geleneği ve Çağdaş Sanatlar Iç̧indeki Yeri Sempozyum Bildirileri, Kültür Bakanlığı Yay., Ankara 1997, s. 335.

${ }^{45}$ Mustafa Çetin Varlık, "Kütahya”, Türkiye Diyanet Vakfi İslam Ansiklopedisi, C. 26, İstanbul 2002, s. 582.

${ }^{46}$ Arthur John Carswell, "Kütahya Çini ve Seramikleri”, Sadberk Hanım Müzesi Türk Çini ve Seramikleri, ed. Ara Altun- Arthur John Carswell- Gönül Öney, Sadberk Hanım Müzesi, İstanbul 1991, s. 56; Belgin Demirsar Arlı, "Kütahya Çiniciliği”, Anadolu'da Türk Devri Çini ve Seramik Sanatı, ed. Gönül Öney-Zehra Çobanlı, Kültür ve Turizm Bakanlığı, İstanbul 2007, s 338; Belgin Demirsar Arlı, "Kütahya Tiles and Ceramics", The Story of Ottoman Tiles and Ceramics, ed. Ara Altun, Instanbul Stock Exchange, İstanbul 1997, s 249; Hülya Bilgi, Kütahya Tiles and Ceramics, Suna ve İnan Kıraç Vakfi, İstanbul 2006, s. 15; Oktay Aslanapa, "Kütahya Keramik Sanatı", Atatürk'ün Doğumunun 100. Yılına Armağan, İstanbul Üniversitesi Edebiyat Fakültesi Yay., İstanbul 1981-1982, s. 141; Şerare Yetkin, "Çini”, Diyanet Vakfi İslam Ansiklopedisi, C. 8, İstanbul 1993, s. 334.

${ }^{47}$ Metin Sözen, Cumhuriyet Dönemi Türk Mimarisi, İş Bankası Kültür Yay., Ankara 1996, s. 17; Metin Sözen, Cumhuriyet Dönemi Türk Mimarlığı. Türkiye İş Bankası Kültür Yay., Ankara 1984, s. 30;Yıldız Demiriz, "Osmanlı Çini Sanatı”, Türkler, ed. Hasan Celal Güzel-Kemal Çiçek, Yeni Türkiye Yay., C. 12, Yeni Türkiye Yay., Ankara 2002, s 572.

${ }^{48}$ Feyzullah Dayıgil, "Çini (Türk Çiniciliği)”, MEB İslam Ansiklopedisi, C. III, 1977, s. 435; Oktay Aslanapa, Türk Sanatı, Remzi Kitabevi, İstanbul 1997, s. 332; Oktay Aslanapa, Anadolu’da Türk Çini ve Seramik Sanatı, Türk Kültürü Araştırma Enstitüsü Yay., İstanbul 1965, s. 35; Oktay Aslanapa, Türkische Fliesen und Keramik in Anatolien, Türk Kültürü Araştırma Enstitüsü Yay., İstanbul 1965, s. 39. 
20. yüzyıl başlarında Kütahya'da çini üretimindeki canlanmadan Tekirdağ Eski Vali Konağı da payını almış, Konağın süslemeleri de söz konusu geleneğe uygun bir şekilde bezenmiştir. Yapıdaki en yoğun çini süslemeler ana kapının olduğu cephedir. Bu dönem özelliklerinden olan ana girişi anıtsal biçimde vurgulanmasına bağlı olarak biçimlenmiştir (Res. 12a-b). Dikdörtgen biçimli, iki kanatlı döküm kapının kanatları simetrik süslemelerle bezenmiştir (Resim 13).

Dört panele ayrılan kapının alt kısmında altı kollu yıldız ve altıgenlerin dönüşümlü yerleştirilmesiyle oluşan geometrik süslemeler yer alır. Yatay ve diğerlerine göre daha küçük olan üst panelde kapı tokmakları yer alır. Üstteki iki panelde ise on iki kollu yıldız ve aralarda düzgün olmayan geometrik biçimlerden oluşan bir bezeme vardır. Kapı, yapının cephelerindeki taş süslemede olduğu gibi, beyaz ve açık kahverengiye boyanmıştır.

Kapının iki yanında madalyonlar içinde Ermeni asıllı çini ustası Stepan Vartanyan'ın desenlerini yapmış olduğunu savladığımız kaplama Kütahya çinileri yer alır (Resim 14). Stepan Vartanyan İstanbul-Topkapı civarında 19. yüzyıl sonu 20. yüzyıl başlarında yaşamış bir desen ustasıdır. Sanatçı pek çok çini deseni hazırlayarak bunları Kütahya'daki çini fabrikalarına göndermiş ve takdirler almıştır. ${ }^{49}$ Garo Kürkman'ın yayımladığı ve bir çini masa deseni olduğunu belirttiği sanatçıya ait desenin (Resim 15) aynısı muhtemelen boyutu küçültülmüş bir madalyon olarak bugün Müze'nin girişini süslemektedir.

Vartanyan Usta'nın daha çok madalyonlar konusunda uzmanlaştığı anlaşılmaktadır. Yapının birazdan değinilecek olan diğer çini kaplamalarının da bu desen ustası tarafından tasarlandığ varsayılabilir. $^{50}$

Söz konusu çini madalyonlarda İznik üretimi eserlerde sıklıkla rastlanan palmet, kıvrık dal, hançer yapraklar ve çiçek motifleriyle hazırlanan bir kompozisyon kullanılmıştır. Bu madalyonların içinde merkezde, yapraklardan oluşan sekiz kollu yıldızdan, yine madalyon şeklinde sekiz yaprağa dönüşen ve içlerinde sekiz yapraklı çiçeklerin yer aldığ 1 bitkisel bir tasarım yer alır. Madalyon dıştan bir şeritle kuşatılmıştır. Firuze, kobalt mavisi, yeşil ve toprak renginin kullanıldığı görülür. Her iki çini madalyonda da görüldügüü gibi tasarım birbirinin aynidir.

Madalyonlar dışında, kapının üzerindeki yatay alanda merkezde çapraz yerleştirilmiş iki çini pano ve yanlarında ikişer firuze, çapraz yerleştirilmiş çini levhalar bulunur (Resim 16).

Çini plakalar benzer süslemelere sahiptir ve üzerinde hatayi, lale, kıvrık dal ve palmetlerden oluşan bitkisel kompozisyon kobalt mavisi, açık mavi, yeşil, beyaz, toprak rengi ile tasarlanmıştır.

Kapı dışarıdan on bir kollu yıldız geçmelerden oluşan iki sıra şeritle kuşatılmıştır. Şerit, madalyonların üzerinden başlayarak kapı üzerindeki kitabeye çerçeve oluşturur (Resim 17a-b).

\footnotetext{
${ }^{49}$ Garo Kürkman, Toprak, Ateş, Sır Tarihsel Gelişimi Atölyeleri ve Ustalarıyla Kütahya Çini ve Seramikler, Suna ve İnan Kıraç Vakfi, İstanbul 2005, s. 239. Faruk Şahin'in makalesinde İstanbul'dan Kambur Stephan (Istapan) olarak bahsettiği desen ustası da Stephan Vartanyan olmalıdır. Araştırmacı, Cumhuriyet dönemi öncesinde Hafız Mehmet Emin Efendi'nin (1872-1922) ve Mehmet Çini'nin atölyelerinden çıkma çini ve seramik desenlerinin bu desen ustasına ait olduklarını, ayrıca kendi arşivinde de sanatçıya ait mührüyle, suluboya ile renklendirilmiş altı tabak deseni olduğundan bahseder. Bu konuda daha fazla bilgi için bkz. Faruk Şahin, "Cumhuriyet Dönemi Kütahya Çini ve Keramik Sanatı", Sanat Tarihi Yıllı̆̆ı , S. 13, 1988, s. 145. Aynı araştırmacı Ahmet Şahin'den aldığı bilgiler doğrultusunda 17.-20. yüzyıllarda Kütahya'da Ermeni asıllı ustaların yoğun olarak çalıştı̆̆ını söyler. Ermeni asıllı ustaların Kütahya atölyelerinde etkin bir şekilde çalıșmaları konusunda bkz. Faruk Şahin, "Kütahya Çini Keramik Sanatı ve Tarihinin Yeni Buluntular Açısından Değerlendirilmesi”, Sanat Tarihi Yıllı̆̆ğ, S. IX-X, 1979-80, s. 270.

${ }^{50}$ Stephan Vartanyan'nın diğer desen tasarımları için bkz. Garo Kürkman, Toprak, Ateş, Sir Tarihsel Gelişimi Atölyeleri ve Ustalarıyla Kütahya Çini ve Seramikler, Suna ve İnan Kıraç Vakfi, İstanbul 2005, s. 203-209.
} 
Kapının üzerinde, konsollar üzerinde küçük yatay bir balkon yükselir. Taş korkulukları altı kollu yıldız ve altıgenlerden oluşur. Balkon kapısı sivri kemerlidir ve köşelerinde yine Kütahya üretimi çiniler yer alır (Resim 18).

Kobalt mavisi, firuze ve mercan kırmızının kullanıldı̆̆ 1 kompozisyon rumilerin oluşturduğu palmet ve kıvrık dalların birbirine dolanmasıyla oluşturulmuştur. Köşeliklerin bittiği üst kısımda, saçak eteğinde bir sıra mukarnas dizisi de Selçuklu ve Osmanlı mimarisini kuvvetle yâd eden bir unsur olarak yerini almıştır.

Batı cephedeki çiniler, üst katın kemer köşelikleri ve kat ayrımını da vurgulayan pencerelerin arasında yer alır. Bunlar dıştan kobalt mavisi ile çerçevelenmiş, şeffaf sırlı firuze renkli çini kaplamalardır (Resim 19). Alt katın dikdörtgen pencerelerinin merkezlerinde dikey yerleştirilmiş panelleri içinde palmet, rumi ve kıvrık dallardan oluşan bitkisel bezemeli kilit taş1 görünümlü paneller yer alır.

Ayrıca katlar arasını vurgulayan çini panellerin üzerinde balkon ve merdiven korkulukları ile kapı üzerinde yer alan yatay dikdörtgen paneller içindeki altı kollu yıldız ve altıgenlerden oluşan, kabartma geometrik kompozisyonlu taş süslemeler cepheye estetik değer katan unsurlardır. Bu tasarımın aynı zamanda yapının süsleme içermeyen tek cephesi olarak kuzey cephe dışında diğer cephelerde de benzer şekilde kullanıldığı görülür.

Bahçeye bakan doğu cephe ise giriş cephesine nispeten sade tasarlanmıştır. Bu cephedeki teras ve balkon korkuluğunda, batı ve güneybatı cephede de görülen altı kollu yıldız ve altıgenlerden oluşan geometrik süsleme yer almaktadır (Res. 9). Ayrıca bu cephenin solundaki dışa taşkın kütlenin üzerinde dikdörtgen pencere üzerinde, merkezdeki yuvarlak iki yanda kare levhalar içinde de bitkisel süslemeler bulunur (Res. 9 ve 20).

Kare levha içinde dört köşede tekrarlanan ve merkezde kıvrık dallarla birbirine bağlanan rumi, palmet ve hatayilerden oluşan bitkisel bir kompozisyon yer alır. Yuvarlak madalyon içinde ise, dört palmete çerçeve oluşturan hatayi ve kıvrık dallardan müteşekkil bir tasarım vardır.

İkinci bir ana kapıyla, bodrum kata açılan daha küçük bir kapının yer aldığı güney cephe, giriş cephesinden sonra en özen gösterilen cephedir ve kısmen ana caddeye bakmaktadır (Res. 10). Kapıya çıkan merdiven korkuluklarında daha önce sözü edilen altı kollu yıldız ve altıgenlerden oluşan geometrik bezeme merdiven korkuluklarında yer alır (Res. 21).

Merdivenle birlikte korkulukların başladığı iki dikey alanda, biri tahrip olmuş iki çini sekizgen levha göze çarpar (Res 22a-b). Bitkisel kompozisyon hançer yapraklar, palmet, kıvrık dallar, beş-altı yapraklı yanı sıra sümbül türü çiçeklerden oluşur. Kompozisyonda mercan kırmızıs1, firuze, kobalt mavisi, yeşil ve kahverengi kullanılmıştır.

Çini panoların yer aldığı başka bir yüzey de kapı üzerindedir (Res. 21-23). İki yanda aynı büyüklük ve süsleme özellikleri taşıyan sekizgen çini panoların arasında, daha küçük boyutlu ve farklı bir süslemenin yer aldığı bir çini pano görülür. Büyük panolarda merkezde dört yapraklı bir çiçekten çıkarak çerçeve oluşturan sekiz hatayi birbirine kıvrık dallarla bağlanmıştır. Bu kompozisyon lotus, rumi ve kıvrık dallardan oluşan bir şerit ile kuşatılmıştır. Ortada yer alan panoda ise sekiz palmet ve ruminin oluşturduğu bitkisel kompozisyon görülür. Bu süsleme, palmetlerle bezenmiş ince bir şeritle kuşatılmıştır.

Yapının çinilerinde yer yer kırılmalar ve sırlarında çatlamalar tespit edilse de genel olarak iyi durumdadır.

Osmanlı döneminde özellikle İstanbul'un iaşesinde önemli bir liman yerleşimi olan Tekirdağ Balkan savaşları, I. Dünya Savaşı ve Millî Mücadele yıllarındaki sıkıntılı süreçte bir gerileme yaşamıştır. Şehir, Edirne vilayeti içinde bir sancak merkezi iken Cumhuriyet 
dönemiyle birlikte vilayet merkezi durumuna getirilir ve yeniden bir canlanma dönemine girer. $\mathrm{Bu}$ dönemde Vali Hikmet Bey tarafından Mimar Tahir'e inşa ettirilen konak yeni anlayış çerçevesinde Osmanlı mimarisinden çağdaş mimarlığa doğru bir değişimin şehirdeki göstergesi olmuştur. Vali Konağı, devletin temsilcisinin yaşam alanı olarak şehirde önemli bir noktada olarak karşımıza çıkar. Yeni devletin gücünün sembolü olan bu yapı döneminde olduğu gibi günümüzde de Tekirdağ'ın en anıtsal yapıları arasında yerini almıştır. Başka bir deyişle konak, inşa edildiği dönemde mimari ve mimari süsleme alanında yeniliğin öncüsü olmuştur. Konak, bu öncülüğü Osmanlı İmparatorluğu'nun son yıllarında kendini göstermeye başlayan ulus-devlet inşasının bir yansıması olarak Ulusal Mimarlık Dönemi anlayışı ile yapmıştır.

Vali konağı binasının girişini vurgulayan taç kapı anlayışı, bodrum kat üzerinde yükselen iki kat, sivri kemerli ve dikdörtgen biçimli pencereler, geometrik bezemeli balkon korkulukları, geniş saçak altında mukarnas kullanımı, taş ve çini bezemeler Selçuklu ve Osmanlı mimarisine ve süslemesine atıf yapmaktadır. Yapının süslemeleri de tıpkı mimarisinde olduğu gibi Selçuklu ve Osmanlı süslemelerine gönderme yapan, 19. yüzyıl başlarında çini ve seramikte yeniden bir canlanma yaşayan Kütahya'da üretilmişlerdir. Konağın çini, taş ve maden süslemeleri Klasik Selçuklu ve Osmanlı süsleme motif/kompozisyonlarının yanı sıra renklerinin de nasıl etüt edildiğini ve geleneğin sonraki yıllarda yeni bir anlayış çerçevesindeki kullanma biçimini göstermeleri bakımından dikkate değerdir.

$\mathrm{Bu}$ hâliyle konak, şehrin sahile hâkim bir noktasında geleneksel Selçuklu ve Osmanlı Sanatı ile Cumhuriyet Dönemi'nin ulusal mimari ve süsleme anlayışı arasında bağ kuran anıtsal bir yap1 olarak yükselir. Konak, aynı zamanda I. Ulusal Mimarlık Dönemi’nin yapım ve süsleme ilkelerinden hareket edilerek inşa edilmesiyle Cumhuriyet Dönemi'nin çağdaşlaşma kavramını şehirde görselleştir.

Şehrin hâlâ simgelerinden biri olan Tekirdağ Eski Vali Konağı, temsil ettiği döneminin düşünsel altyapının yanı sıra, şehrin yönetimsel gereksinimlerine çağdaş bir şekilde cevap vermek üzere tasarlanmıştır.

\section{Kaynakça}

Akarsu, Hasan, Tekirdağ Sonsuz Gurbet, Heyamola Yay., İstanbul 2010.

Akşin, Sina, "Türk Ulusçuluğu”, Cumhuriyet Dönemi Türkiye Ansiklopedisi, C. 7, İstanbul: İletişim Yay., 2002, s. 1941-1942.

Aktüre, Sevgi, “Osmanlı Devleti'nde Taşra Kentlerindeki Değişimler”, Tanzimat'tan Cumhuriyet'e Türkiye Ansiklopedisi, C. 4, İletişim Yay., İstanbul 1985, s. 891-904.

Alpagut, Leyla, “1930’larda Bir Mimar: İzzet Baysal”, Edebiyat Fakültesi Dergisi, S. 26-1, Haziran, 2009, s. 13-32.

Alsaç, Üstün, “Türkiye Mimarlık Düşüncesinin Cumhuriyet Dönemindeki Evrimi”, Mimarlık Dergisi, S. 11-12 (121), 1973, s. 12-25.

Alsaç, Üstün, Türk Mimarlı̆̆g, İletişim Yay., İstanbul 1992.

Alsaç, Üstün, Türkiye'deki Mimarlı Düşüncesinin Cumhuriyet Dönemindeki Evrimi. Karadeniz Teknik Üniversitesi Bask1 Atelyesi, Trabzon 1976.

Anonim, Kültür Envanteri, Tekirdağ Belediye Başkanlığı, Tekirdă̆ 2007.

Arık, Rüçhan, Batılılaşma Dönemi Anadolu Tasvir Sanatı, Türkiye İş Bankası Yayını, Ankara 1976.

Arlı, Belgin Demirsar, "Kütahya Çiniciliği”, Anadolu'da Türk Devri Çini ve Seramik Sanatı, ed. Gönül Öney-Zehra Çobanl1, Kültür ve Turizm Bakanlığı, İstanbul 2007, s. 329-345. 
Arl1, Belgin Demirsar, "Kütahya Tiles and Ceramics", The Story of Ottoman Tiles and Ceramics, ed. Ara Altun, Instanbul Stock Exchange, İstanbul 1997, s. 237-256.

Arseven, Celal Esat, Türk Sanatı, Cem Yayınevi, İstanbul 1984.

Aslanapa, Oktay, "Kütahya Keramik Sanatı”, Atatürk'ün. Doğumunun 100. Yllına Armağan, İstanbul Üniversitesi Edebiyat Fakültesi Yay., İstanbul 1981- 1982, s. 69-170.

Aslanapa, Oktay, Anadolu'da Türk Çini ve Seramik Sanatı, Türk Kültürü Araştırma Enstitüsü Yay., İstanbul 1965.

Aslanapa, Oktay, Osmanlılar Devrinde Kütahya Çinileri, İstanbul Üniversitesi Edebiyat Fakültesi Yay., Üçler Basımevi, İstanbul 1949.

Aslanapa, Oktay, Türk Sanatı, Remzi Kitabevi, İstanbul 1997.

Aslanapa, Oktay, Türkische Fliesen und Keramik in Anatolien, Türk Kültürü Araştırma Enstitüsü Yay., İstanbul 1965.

Aslanoğlu, İnci, “1930'lar: Türk Mimarisinde Erken Modernizm”, Cumhuriyet'in Mekânları / Zamanlan / İnsanlarl, ed. Altan Elvan Ergut-Bilge İmamoğlu, Dipnot Yay., Ankara, 2010, s. 25-30.

Aslanoğlu, İnci, "Birinci ve İkinci Milli Mimarlık Akımları Üzerine Düşünceler", Mimaride Türk Milli Üslubu Semineri, İstanbul, 11-12 Haziran 1984, Atatürk Kültür Merkezi Yay., İstanbul 1984, s. 41-51.

Aslanoğlu, İnci, “Cumhuriyetin İlk Yıllarında Mimari”, Türkler, C. 18, ed. Hasan Celal GüzelKemal Çiçek, Yeni Türkiye Yay., Ankara, 2002, s. 253-258.

Aslanoğlu, İnci, "Modernizmin Başlangıç Aşamasında 1926/33 Yılları Arası Türk Mimarlığında Yaşanan Gelişmelerin Bir Değerlendirmesi”, Prof. Doğan Kuban'a Armă̆an, ed. Zeynep Ahunbay- Deniz Mazlum, Eren Yay., İstanbul 1996, s. 17-24.

Aslanoğlu, İnci, “Söyleşi: Osmanlı'dan Bugüne Hükûmet Konakları”, Mimarlık, S. 203, 1984, s. 3-15.

Aslanoğlu, İnci, Erken Cumhuriyet Dönemi Mimarlığı, Bilge Kültür Sanat Yay., İstanbul 2010.

Ateş, Hacer, “Tekirdağ”, Diyanet Vakfi İslam Ansiklopedisi, C. 40, İstanbul 2011, s. 359-362.

Aygün, Necmettin, "XIX Yüzyıl Başlarında İstanbul Merkezli Osmanlı Deniz Taşımacılığı". OTAM, S. 23, Bahar, 2008, s. 53-84.

Başkan, Seyfi, "Cumhuriyet Döneminde Sanat", Türkler, C. 18, ed. Hasan Celal Güzel-Kemal Çiçek, Yeni Türkiye Yay., Ankara 2002, s. 233-252.

Başkan, Seyfi, "Türk Modernleşmesi ve Erken Cumhuriyet Döneminin 'Milli Mimarlığı", Turkish Studies International Periodical for the Languages, Literature and History, Volume: 11/13, 2016, s. 97-116.

Batur, Afife, “1925-50 Döneminde Türkiye Mimarlığı”, 75 yılda Değişen Kent ve Mimarlık, ed. Yıldız Sey-Derya Özkan, Türkiye Ekonomik ve Toplumsal Tarih Vakfi, İstanbul 1998, s. 209-234.

Batur, Afife, "Batılılaşma Döneminde Osmanlı Mimarlı̆̆ı", Tanzimattan Cumhuriyete Osmanlı Ansiklopedisi, C. 4, İletişim Yay., İstanbul 1986, s. 1038-1067.

Batur, Afife, "Cumhuriyet Dönemi Mimarlığı", Dünden Bugüne İstanbul Ansiklopedisi, C. 2, Tarih Vakfi Yurt Yay., İstanbul 1994, s. 449-450. 
Batur, Afife, "Cumhuriyet Döneminde Türk Mimarlı̆̆ı", Cumhuriyet Dönemi Türkiye Ansiklopedisi, C. 5, Hazırlayan: Murat Belge-Seyfettin Gürsel-Mete Tunçay, İletişim Yay., İstanbul 1993, s. 1379-1420.

Batur, Afife, “Milli Olarak Adlandırılan Mimari Eğilimler”, Mimarlı, S. 298, 2001, s. 42-46.

Batur, Afife, "Modern Olmak: Bir Cumhuriyet Mimarlığı Arayışı”, Modern Türk Mimarlığı, ed. Ahmet Evin-Renate Holod- Süha Özkan, TMMOB Mimarlar Odası Yay. Yalçın Matbaacılik, Ankara 2007, s.70-96.

Batur, Afife, Vedat Tek Kimliğin İzinde Bir Mimar, Yap1 ve Kredi Yay., İstanbul 2002.

Bektaş, Cengiz, "Mimarlığımızın Cumhuriyeti Cumhuriyet Dönemine Bir Bakış”, Ege Mimarlık Dergisi, S. 30, 1999, s. 27-30.

Bektaş, Cengiz, "Mimarlığımızın Cumhuriyeti Cumhuriyet Dönemine Bir Bakış", Yeni Türkiye Dergisi, Cumhuriyet Özel Sayısı 4. Kültürel Değerlendirme, S. 23-24, Eylül-Aralık, 1998, s. 3066-3076.

Berkes, Niyazi, Türkiye'de Çağdaşlaşma, Bilgi Yayınevi, Ankara 1973.

Bilgi, Hülya, "İslam Öncesi Kütahya Yöresi Seramik Sanatı”, Toprak, Ateş, Sir, Tarihsel Gelişimi Atölyeleri ve Ustalarıyla Kütahya Çini ve Seramikler, Hazırlayan: Garo Kürkman, Suna ve İnan Kıraç Vakfı Yay., İstanbul 2005, s. 14-29

Bilgi, Hülya, Kütahya Tiles and Ceramics, Suna ve İnan Kıraç Vakfı, İstanbul 2006.

Bozdoğan, Sibel, "Türk Mimari Kültüründe Modernizm: Genel Bir Bakış", Türkiye’de Modernleşme ve Ulusal Kimlik, ed. Sibel Bozdoğan, Reşat Kasaba, Tarih Vakfi Yay., İstanbul 1998, s. 118-135.

Bozdoğan, Sibel, Modernizm ve Ulusun İnşası: Erken Cumhuriyet Türkiyesinde Mimari Kültür, Çeviren: Tuncay Birkan, Metis Yay., İstanbul 2002.

Carswell, Arthur John, “Kütahya Çini ve Seramikleri”, Sadberk Hanım Müzesi Türk Çini ve Seramikleri, ed. Ara Altun- Arthur John Carswell- Gönül Öney, Sadberk Hanım Müzesi, İstanbul 1991, s. 49-102

Cengizkan, Ali, "Birinci Ulusal Mimarlık "Savunma Hattı'nda", Modernin Saati, Mimarlar Derneği-Boyut Yay., Ankara 2002, s. 61-69.

Çadırcı, Musa Tanzimat Döneminde Anadolu Kentlerinin Sosyal ve Ekonomik Yapıları. Türk Tarih Kurumu Yay., Ankara 1991.

Çevik, Hikmet, Tekirdağ Tarihi Araştırmaları, Ahmet Sait Basımevi, İstanbul 1949.

Çıkış, Şeniz, "Birinci Ulusal Mimarlık Dönemi İzmir Konutu: Yerellik ve Melezlik", METU Journal of the Faculty of Architecture, S. 28-2, 2011, s. 45-61.

Çini, Rıfat, Kütahya in Turkish Tile Making. Uycan Yay., İstanbul 1991.

Çini, Rifat, Türk Çiniciliğinde Kütahya, Uycan Yay., İstanbul 1991.

Darkot, Besim, “Tekirdağ”, MEB İslam Ansiklopedisi, C. 12/1, MEB Devlet Kitapları, Eskişehir 2001, s. 133-135.

Dayıgil, Feyzullah, “Çini (Türk çiniciliği)”, MEB İslam Ansiklopedisi, C. III, 1977, s. 430-435.

Demiriz, Yıldız, "Osmanlı Çini Sanatı", Türkler, C. 12, ed. Hasan Celal Güzel-Kemal Çiçek, Yeni Türkiye Yay., , Yeni Türkiye Yay., Ankara 2002, s. 563-572.

Ekin Ümit-Hümmet Kanal, “Tekfurdağı Sancağı'nın Sosyal ve Ekonomik Yapısı (1890-1902)”, HUMANITAS, S. 4, 2014, s. 109-127. 
Eldem, Sedat Hakk1, “Elli Yıllık Cumhuriyet Mimarlı̆̆ı”, Mimarlık, S. 121-122, 1973, s. 5-11.

Ergut, Altan Elvan, "Sınırlar ve Sorunlar Üzerine Düşünceler Erken Cumhuriyet Dönemi ve Ulusal Mimarlık”, Toplumsal Tarih Dergisi, S. 189, 2009, s. 76-82.

Ertuğrul, Zeynep, Birinci Ulusal Mimarlı Dönemi Mimarlarından Muzaffer Bey: Eserleri ve Sanat Anlayışıı, Yayımlanmamış Doktora Tezi, Anadolu Üniversitesi Sosyal Bilimler Enstitüsü, Eskişehir 2007.

Eyice, Semavi, "Batı Sanat Akımlarının Değiştirdiği Osmanlı Dönemi Türk Sanatı", Türkler, ed. Hasan Celal Güzel-Kemal Çiçek-Salim Koca, cilt 15, Ankara 2002, s. 284-309.

Eyice, Semavi, "Batılılaşma. Mimari”, Diyanet Vakfi İslam Ansiklopedisi, Cilt 5, İstanbul 1992, s. $171-181$.

Eyice, Semavi, "XVIII. Yüzyılda Türk Sanatı ve Türk Mimarisinde Avrupa Neoklasik Üslubu”, Sanat Tarihi Ylllı̆̆

Faroqhi, Süreyya, Osmanlı Şehirleri ve Kırsal Hayatı, Çeviren: E. S. Özcan, Doğubatı Yay., Ankara 2006.

Gül, Murat, "Erken Dönem Cumhuriyet Mimarisinin İmparatorluk ve Cumhuriyet Devri Çağdaşlaşma Çabalarının İlişkisi Bakımından İncelenmesi”, Cumhuriyet'in Mekânları / Zamanlan / Insanları, ed. Altan Elvan Ergut-Bilge İmamoğlu, Dipnot Yay., Ankara 2010, s. $275-287$

Hasol, Doğan, Ansiklopedik Mimarlık Sözlüğü, Yapı Endüstri Merkezi, İstanbul 1998.

Işın, Mehmet Akif-Mehmet Serez vd., Yaşayan Tekirdăg, Hazırlayan: Sezai Kurt, TC Tekirdăg Valiliği Yay., İstanbul 2003.

İnciciyan, L. H. Hrand D. Andreasyan, “ Osmanlı Rumelisi’nin Tarihi ve Coğrafyası”, Güneydoğu Avrupa Araştırmaları Dergisi, S. 4-5, İstanbul, 1976, s. 101-152.

Kınık, Doğan, “Tekirdağ”, Eczacıbaşı Sanat Ansiklopedisi, C. 3, Yem Yay., İstanbul 1997, s. 1755-1756.

Kızıl, Mustafa, Cumhuriyet Dönemi Kütahya Çinisinde Görülen Uygulama Teknikleri ve Yenilikler, Yayımlanmamış Yüksek Lisans Tezi, Kocatepe Üniversitesi Sosyal Bilimler Enstitüsü, Afyon 2010.

Koyunoğlu, Arif Hikmet, “Türk Mimarisinde Çini Sanatı ve Bezemeleri”, Mimarlık, S. 7, 1984, s. $10-11$.

Köse, Ebru, Sadberk Hanım Müzesi Teşhirindeki Sinırlı Sayıda Kütahya Çini Koleksiyonunun Belgelenmesi, Yayımlanmamış Yüksek Lisans Tezi, Gazi Üniversitesi Eğitim Bilimleri Enstitüsü, Ankara 2014.

Kuban, Doğan, "Türk Mimarisi'nde Barok ve Rokoko", Türk ve İslâm Sanatı Üzerine Denemeler, Arkeoloji ve Sanat Yay., İstanbul 1995, s. 131-139.

Kuban, Doğan, Türk Barok Mimarisi Hakkında Bir Deneme, Pulhan Matbaası, İstanbul 1954.

Kuran, Abdullah, "Mimarlıkta "Yeni-Türk” Üslubu ve Osman Hamdi Bey”, Selçuklular'dan Cumhuriyet'e Türkiye'de Mimarlık, ed. Çiğdem Kafesçioğlu- Lucienne Thys-ŞenocakTimur Kuran, Türkiye İş Bankas1 Yay., İstanbul 2012, s. 597-603.

Kuruyazıcı, Hasan, Osmanlı'dan Cumhuriyet'e Bir Mimar Arif Hükmet Koyunoğlu, Anılar, Yazılar, Mektuplar, Belgeler, Yap1 Kredi Yay., İstanbul 2008.

Kürkman, Garo, Toprak, Ateş, Str Tarihsel Gelişimi Atölyeleri ve Ustalarıyla Kütahya Çini ve Seramikler, Suna ve İnan Kıraç Vakfı, İstanbul 2005. 
Mortaş, Abidin, "Hükûmet Konakları”, Arkitekt, S. 11-12, 1944, s. 250-252.

Nurcan, İnci Fırat, "XX. Yüzyıl Başlarında Görülen Osmanlı Mimarisi”, Türkler, C. 10, ed. Hasan Celal Güzel-Kemal Çiçek, Yeni Türkiye Yay., Ankara 1999, s. 287-297.

Nurcan, İnci Fırat, Ankara'da Cumhuriyet Dönemi Mimarisinden İki Örnek, Kültür Bakanlı̆̆ı Yay., Ankara 1998.

Ortaylı, İlber, “Söyleşi: Osmanlı'dan Bugüne Hükûmet Konakları”, Mimarlık, S. 203, 1984, s. 3-15.

Ödekan, Ayla, "Çağdan Olmak", Cumhuriyet'in Renkleri, Biçimleri, ed. Ayla Ödekan, Tarih Vakfi Yay., İstanbul 1999, s. 3-5.

Ödekan, Ayla, "Mimarlık ve Sanat Tarihi (1908-1980)”, Türkiye Tarihi 4 Çağdaş Türkiye 19081980, ed. Sina Akşin, Cem Yayınevi, İstanbul 1997, s. 505-588.

Öndin, Nilüfer, Cumhuriyet'in Kültür Politikası ve Sanat 1923-1950, İnsanc1l Yay., İstanbul 2003.

Öney, Gönül, İslâm Mimarisinde Çini. Ada Yay., İstanbul 1987.

Renda, Günsel, "Yenileşme Döneminde Kültür ve Sanat," Türkler, C. 15, Yeni Türkiye Stratejik Araştırma Merkezi, Ankara 2002, s. 265-283.

Sayar, Yasemin, "Türkiye'de Modernleşme ve Milliyetçilik: Milli Kimlik Sorunu ve Mimari İfadesi”, Mimarlık, S. 291, 2000, s. 48-52.

Sayar, Zeki, “Mimarlığımız: 1923-1950”, Mimarlık, S. 2, 1973, s. 20-23.

Serez, Mehmet, Tekirdăg Tarihi ve Coğrafyası Araştırmaları, Dönmez Ofset, Ankara 2007.

Sönmez, Zeki, "Cumhuriyet Dönemi Mimarlığının Fikir Temelleri”, Cumhuriyet'in Yetmiş Beş Yllında Kültür ve Sanat Sempozyum Bildiriler,. 18-19 Mart 1999, İstanbul Sanat Tarihi Derneği Yay., 2000, s. 63-70.

Söylemezoğlu, Hamit Kemalî, “ Mimarlığımız: 1923-1950”, Mimarlık, S. 2, 1973, s. 26-33.

Sözen, Metin- Mete Tapan, 50 Yllın Türk Mimarisi, İş Bankası Kültür Yay., İstanbul 1973.

Sözen, Metin, "Birinci Ulusal Mimarlık Dönemi ve Mimarları", Mimaride Türk Milli Üslubu Semineri, İstanbul 11-12 Haziran 1984 Bildiriler, Atatürk Kültür Merkezi Yay., İstanbul 1984, s. 35-39.

Sözen, Metin, Cumhuriyet Dönemi Türk Mimarisi, İş Bankası Kültür Yay., Ankara 1996.

Sözen, Metin, Cumhuriyet Dönemi Türk Mimarlı̆̆l, Türkiye İş Bankası Kültür Yay., Ankara 1984.

Sümer, Güner, "Kütahya Çinisi ve Günümüzdeki Durumu”, Türkiye’de El Sanatları Geleneği ve Çağdaş Sanatlar İçindeki Yeri Sempozyum Bildirileri, Kültür Bakanlığ̀ Yay., Ankara 1997, s. 334-361.

Şahin, Faruk, "Cumhuriyet Dönemi Kütahya Çini ve Keramik Sanatı", Sanat Tarihi Yıllı̆̆g, S. 13, 1988, s. 131-152.

Şahin, Faruk, "Kütahya Çini Keramik Sanatı ve Tarihinin Yeni Buluntular Açısından Değerlendirilmesi”, Sanat Tarihi Yıllı̆̆ı, S. IX-X, 1979-80, s. 259-286.

Tan, Nail, Cumhuriyet Dönemi Kültür Çalışmalarının Dünü Bugünü Yarını, (Bir Kültür Politikası Oluşumu), BRC Basım Matbaacılık, Ankara 2003.

Tapan, Mete "Türkiye'de Uygarlık, Bayındırlık, Kentleşme ve Atatürk”, Çağdaş Düşüncenin Işı̆ğında Atatürk, Dr. Nejat F. Eczacıbaşı Vakfı Yay., İstanbul 1983, s. 379-413. 
Tekeli, İlhan, "Mimar Kemalettin ve Eseri Hangi Ortamda Gelişti”, Mimar Kemalettin ve Çă̆ı: Mimarlık/Toplumsal Yaşam /Politika, ed. Ali Cengizkan, TMMOB Mimarlar Odası ve Vakıflar Genel Müdürlüğü Yay., Ankara 2009, s. 23-39.

Tekeli, İlhan, "Türkiye'de Mimarlı̆̆ın Gelişiminin Toplumsal Bağlamı”, Modern Türk Mimarlı̆̆l, ed. Ahmet Evin-Renate Holod- Süha Özkan, TMMOB Mimarlar Odası Yay. Yalçın Matbaacılık, Ankara 2007, s. 15-36.

Toybıyık Nazif -Mustafa Özkabak vd., Tekirdă̆ Marmara'nın İncisi, Tekirdağ Valiliği Yay., Tekirdağ 1992.

Tuğlacı, Pars, Osmanlı Şehirleri, Milliyet Yay., İstanbul 1985.

Tuncel, Mehmet, "Tekirdağ (Bugünkü Tekirdağ)", Diyanet Vakfi İslam Ansiklopedisi, C. 40, İstanbul 2011, s. 362-364.

Tuncel, Mehmet, "Türkiye'de Kıyı Taraçaları Üzerinde Kurulan Şehirler: Tekirdağ Örneği”, Rodos'tan Süleymanpaşa'ya Tekirdă̆, Uluslararası Tekirdă̆ Tarihi Sempozyumu Bildirileri, Tekirdăg 26-27 Mart 2015 Namık Kemal Üniversitesi, ed. Mehmet Y1ldı, Kitabevi, İstanbul 2016, s. 63-66

Tuncer, Orhan Cezmi, "Mimaride Türk Milli Üslubu İlkeleri”, Mimaride Türk Milli Üslubu Semineri. İstanbul, 11-12 Haziran 1984 Bildiriler, Atatürk Kültür Merkezi Yay., İstanbul 1984, s. 67-69.

Varlık, Mustafa Çetin, "Kütahya", Türkiye Diyanet Vakfi İslam Ansiklopedisi, C. 26, İstanbul 2002, s. 580-584

Yavuz, Yıldırım- Süha Özkan, "Osmanlı İmparatorluğunun Son Yılları", Modern Türk Mimarlı̆̆l, ed. Ahmet Evin-Renate Holod- Süha Özkan, TMMOB Mimarlar Odas1 Yay. Yalçın Matbaacılık, Ankara 2007, s. 38-52.

Yavuz, Yıldırım- Süha Özkan, “Osmanlı Mimarlığının Son Yılları”, Tanzimattan Cumhuriyete Türkiye Ansiklopedisi, C. 4, İletişim Yay., İstanbul 1985, s. 1078-1090.

Yavuz, Yıldırım- Süha Özkan, "Ulusal Bir İfade Bulmak: Birinci Ulusal Üslup”, Modern Türk Mimarlığ, ed. Ahmet Evin-Renate Holod- Süha Özkan, TMMOB Mimarlar Odası Yay., Yalçın Matbaacılık, Ankara 2007, s. 55-68.

Yavuz, Yıldırım, “İkinci Meşrutiyet Döneminde Ulusal Mimari Üzerindeki Batı Etkileri”, ODTÜ Mimarlık Fakültesi Dergisi, S. 2-1, 1976, s. 9-31.

Yavuz, Yıldırım, “Mimar Kemalettin Bey (1870-1927)”, ODTÜ Mimarlık Fakültesi Dergisi, S. 7-1, 1981, s. 53-76.

Yavuz, Yıldırım, "Tek Vedat”, Dünden Bugüne İstanbul Ansiklopedisi, C. 7, Tarih Vakfı Yurt Yay., İstanbul 1994, s. 232.

Yavuz, Yıldırım, "Yeni Bulguların Ișı̆ı̆ında Mimar Kemalettin ve Yapıtları”, Mimar Kemalettin ve Çă̆l: Mimarlık / Toplumsal Yaşam / Politika, ed. Ali Cengizkan, TMMOB Mimarlar Odası ve TC. Başbakanlık Vakıflar Genel Müdürlüğü Yay., Ankara 2009, s. 129-140.

Yavuz, Yıldırım, Imparatorluktan Cumhuriyete Mimar Kemalettin, 1870-1927, Vakıflar Genel Müdürlüğü TMMOB Mimarlar Odası, Ankara 2009.

Yavuz, Yıldırım, Mimar Kemalettin ve I. Ulusal Mimarlık Dönemi, Ortadoğu Teknik Üniversitesi Yay., Ankara 1981.

Yazıcı, Nurcan, “Amasya'daki Hükûmet Konağı Binaları”, Sanat Dergisi, Atatürk Üniversitesi Güzel Sanatlar Fakültesi Dergisi, S. 18, 2010, s. 91-105. 
Yazıc1, Nurcan, “Trabzon Örneğinde Tanzimat'tan Cumhuriyet'e Hükûmet Konağı Binaları”, Uluslararası Sosyal Araştırmalar Dergisi, S. 1-5, 2008, s. 943-959.

Yetkin, Şerare, "Çini”, Diyanet Vakfi İslam Ansiklopedisi, C. 8, İstanbul 1993, s. 329-335.

Yıldız Murat - Nuran Koltuk, Arşiv Belgelerine Göre XVII-XX. Yüzylllarda Tekirdağ'da Ekonomik Hayat, Kitapevi, İstanbul, 2016. 


\section{Resimler:}

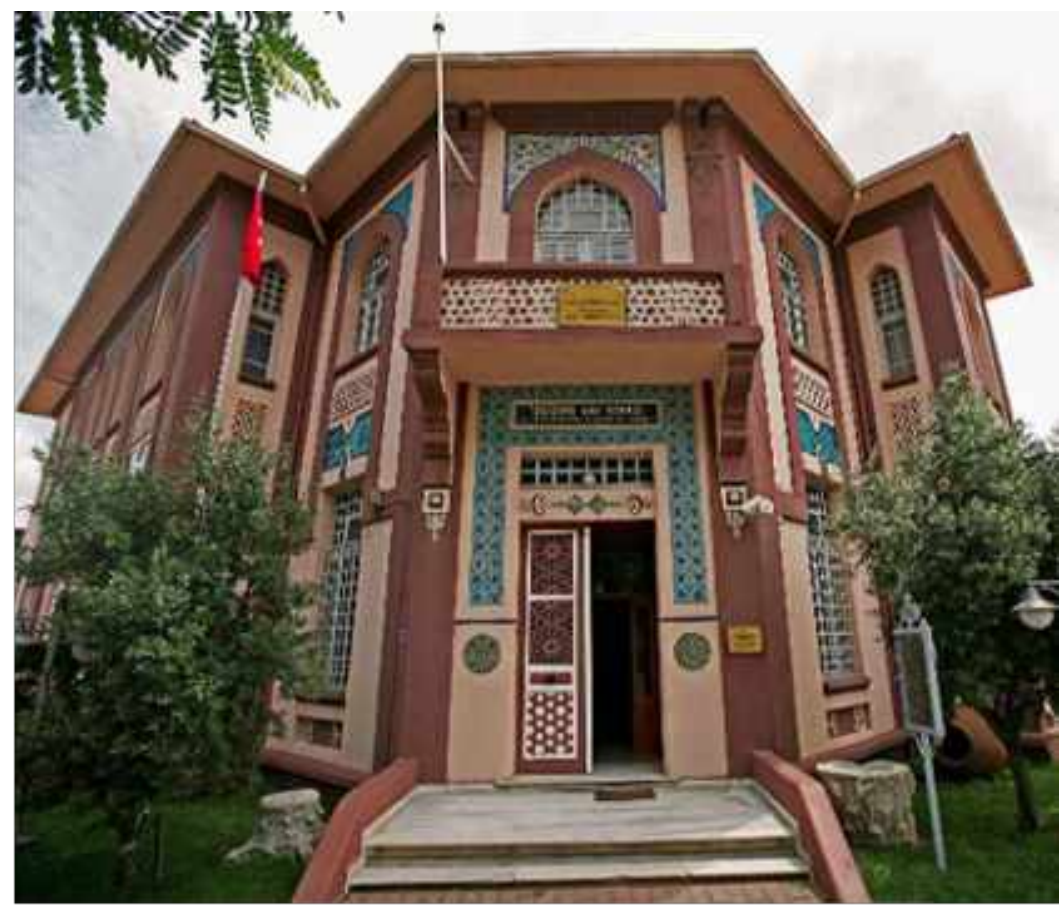

Res. 1. Tekirdağ Eski Vali Konağı, Barbaros Caddesi’ne bakan ana giriş (Fot. S. Altıer 2017)

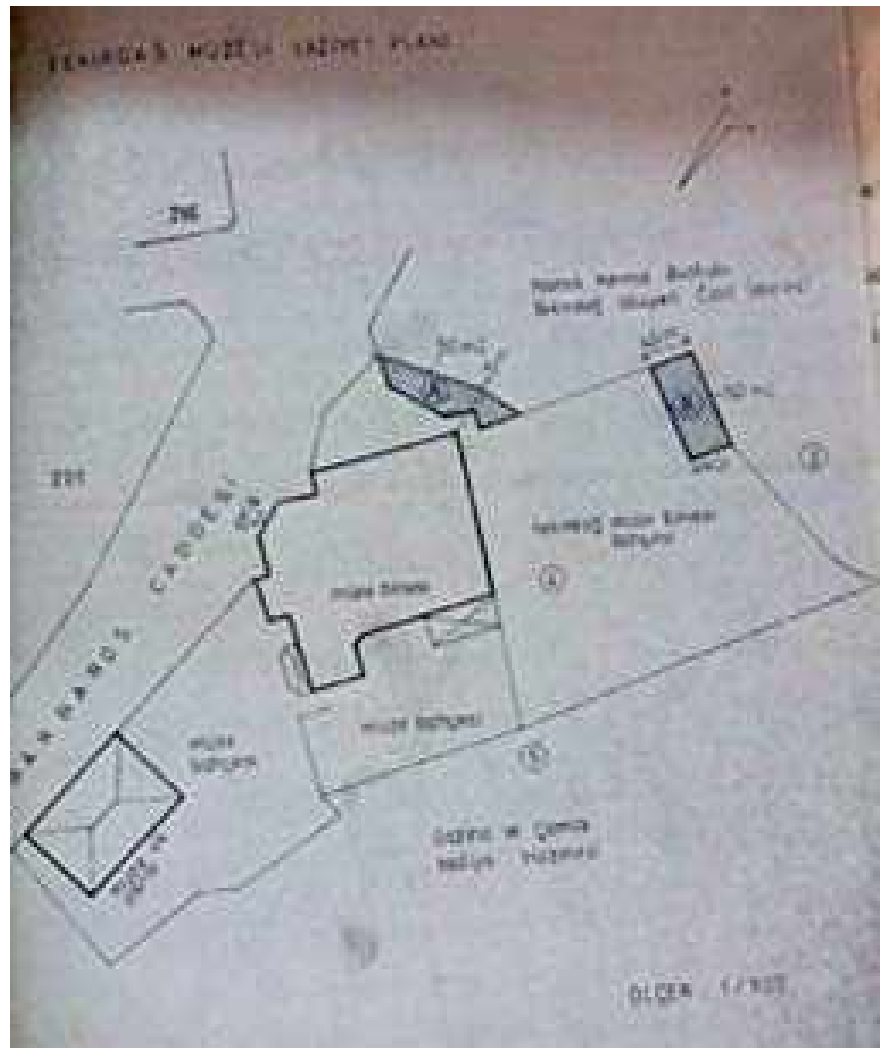

Res. 2. Tekirdağ Eski Vali Konağ1, vaziyet planı (Tekirdağ Arkeoloji ve Etnoğrafya Müzesi Arşivinden) 


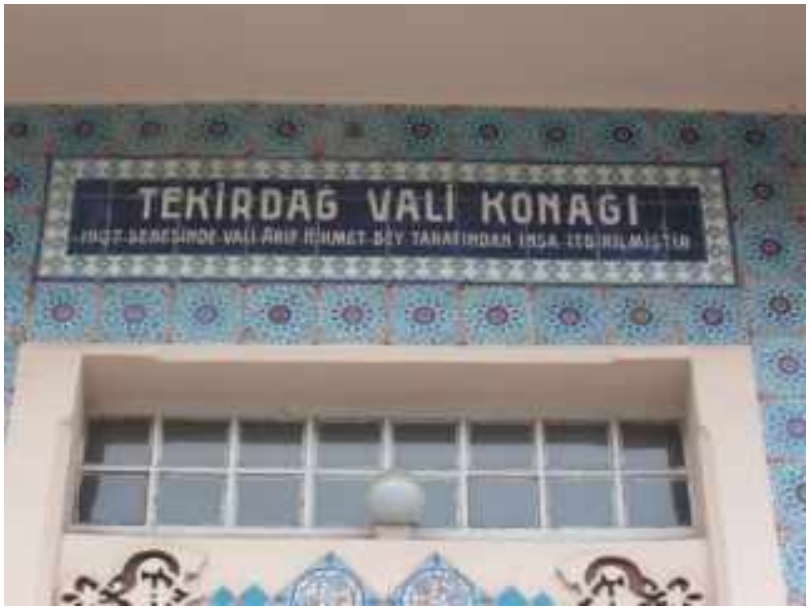

Res. 3. Tekirdağ Eski Vali Konağı, Ana giriş kapısı üzerinde inşa kitabesi (Fot. S. Altıer 2017)

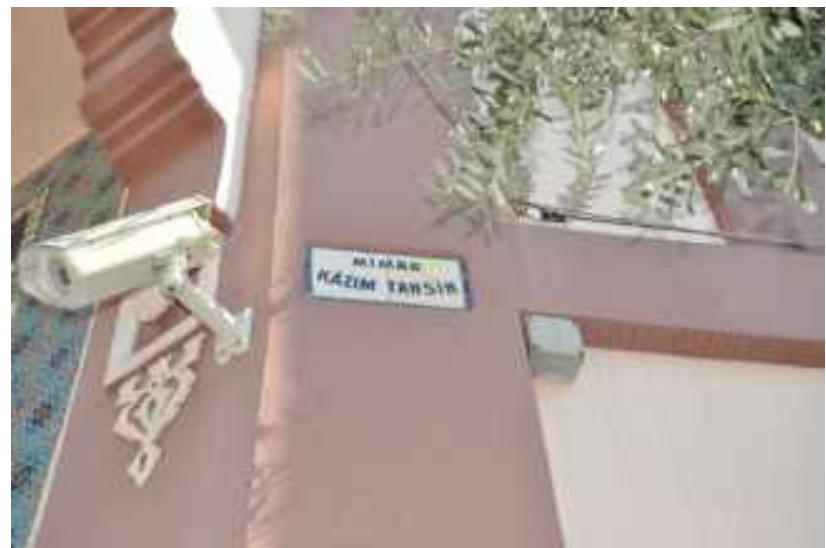

Res. 4. Tekirdağ Eski Vali Konağı, mimar kitabesi (Fot. S. Altıer 2017)

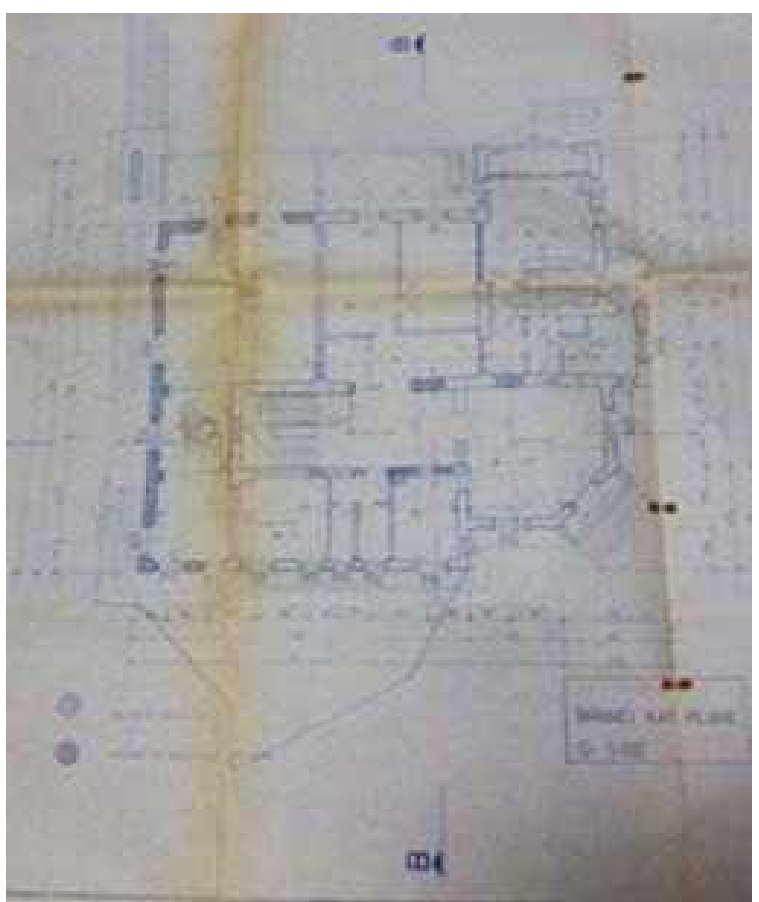

Res. 5. Tekirdağ Eski Vali Konağı, birinci kat planı (Tekirdağ Arkeloji ve Etnoğrafya Müzesi Arşivinden) 


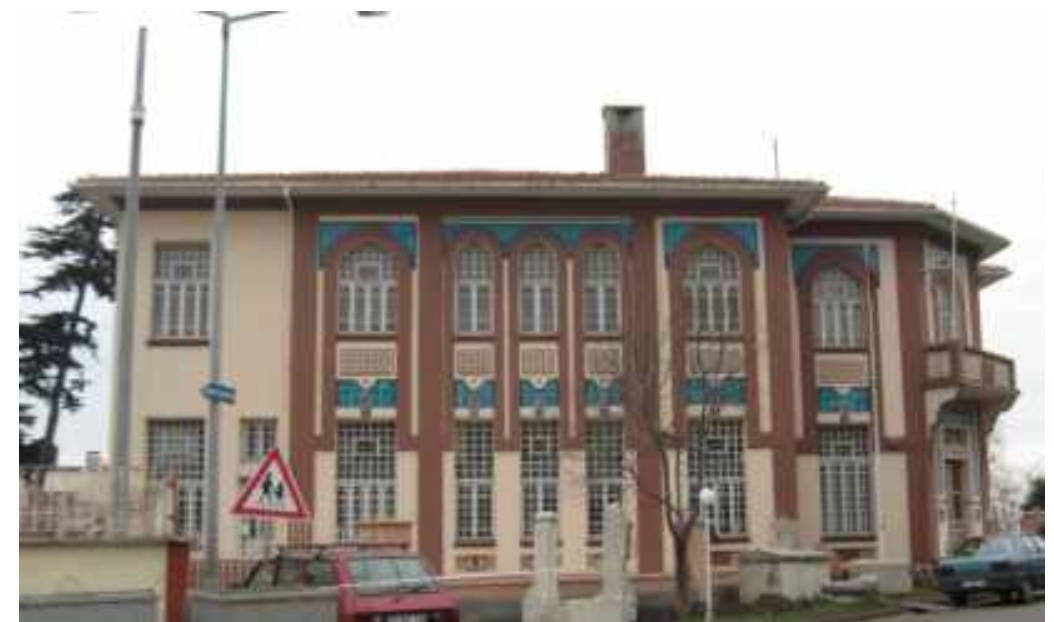

Res. 6. Tekirdağ Eski Vali Konağı, batı ve güney batı cephe (Fot. S. Altıer 2017)

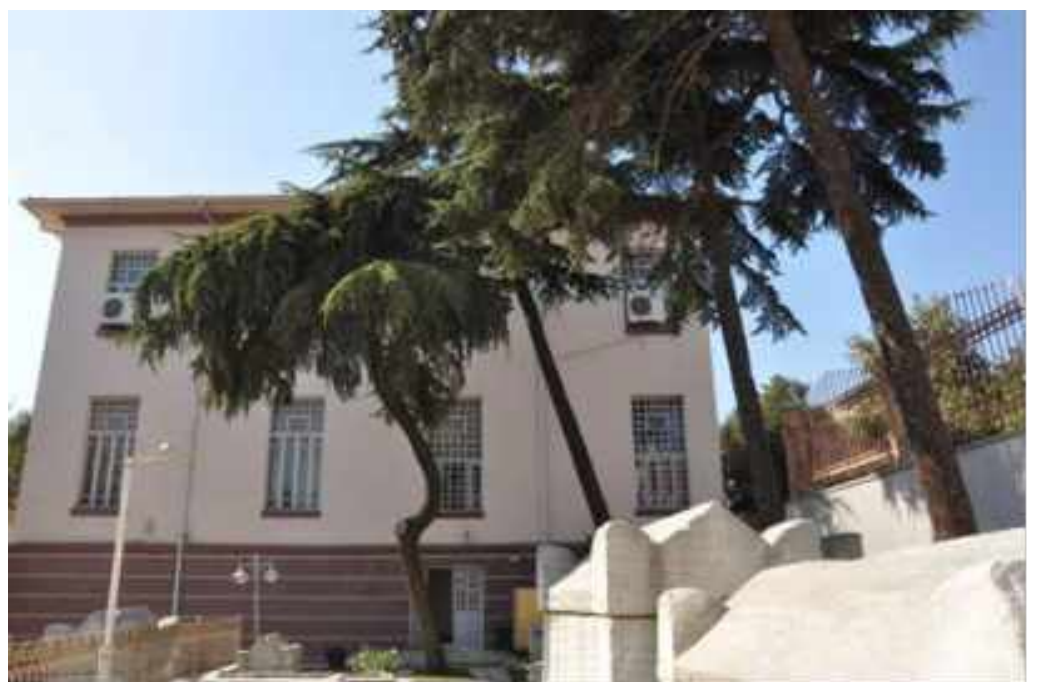

Res. 7. Tekirdağ Eski Vali Konağı, kuzey cephe (Fot. S. Altıer 2017)

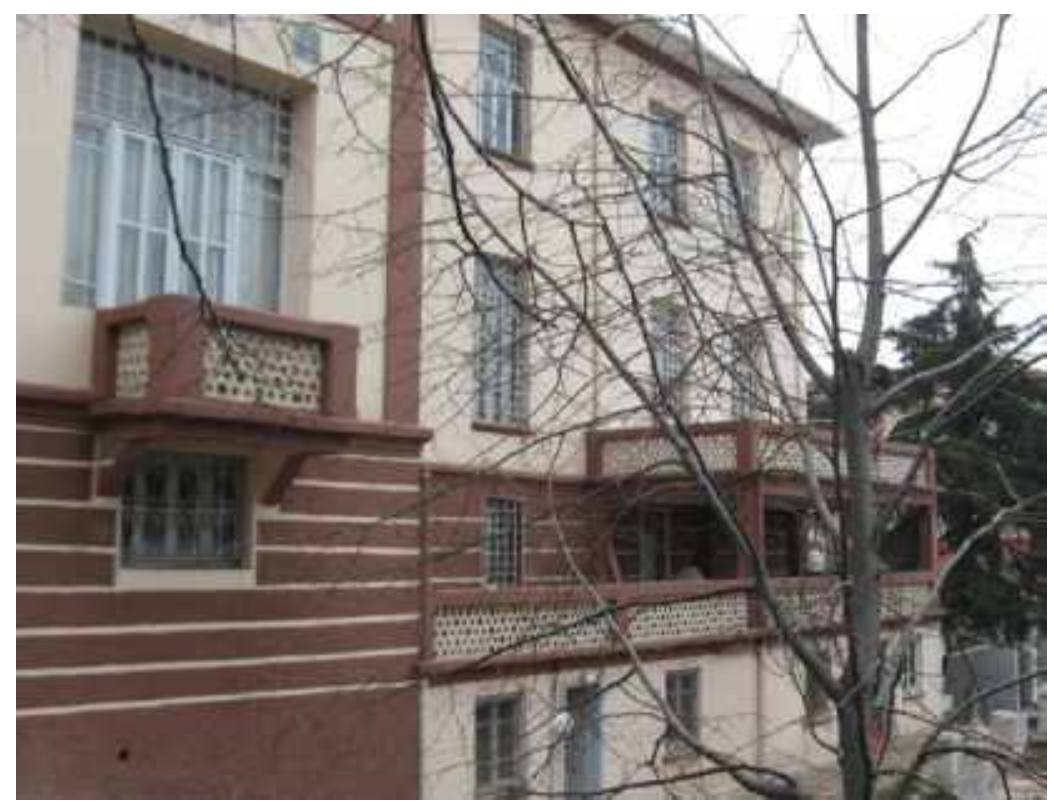

Res. 8. Tekirdağ Eski Vali Konağı, doğu cephe (Fot. S. Altıer 2017) 


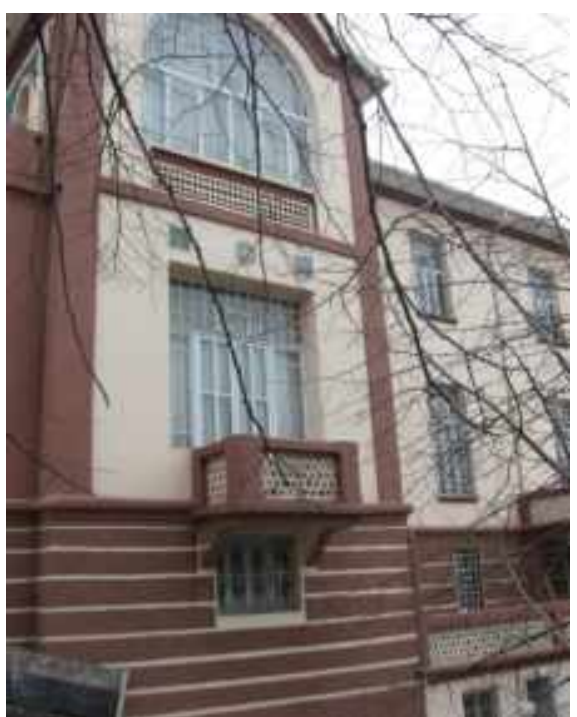

Res. 9. Tekirdağ Eski Vali Konağı, doğu cephe (Fot. S. Altıer 2017)

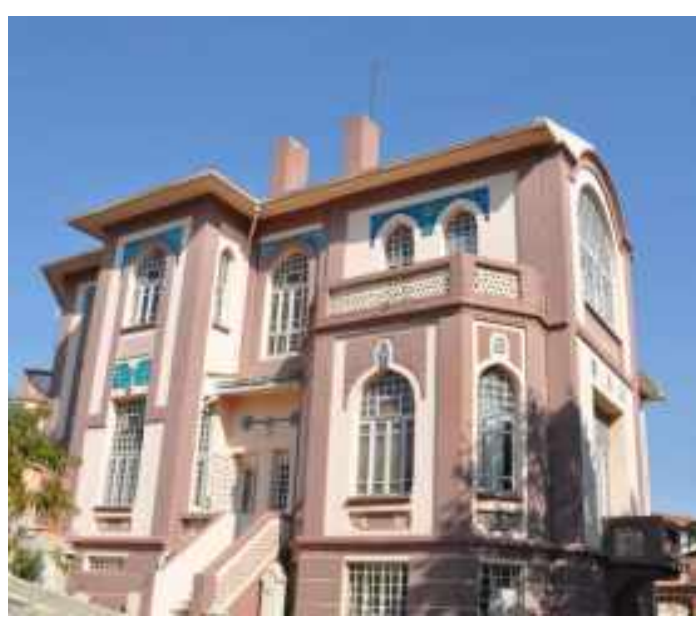

Res. 10. Tekirdağ Eski Vali Konağı, güney cephe (Fot. S. Altıer 2017)

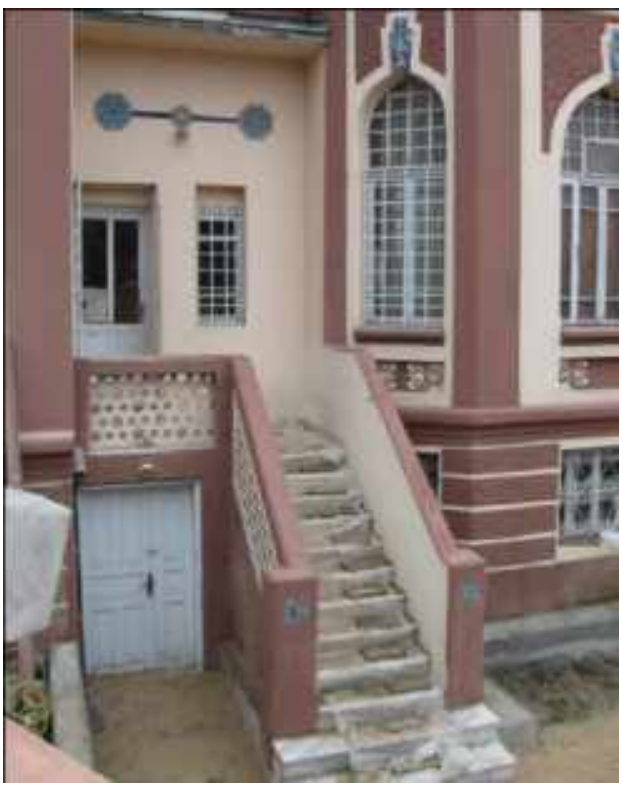

Res. 11. Tekirdağ Eski Vali Konağı, güney cephe kapıları (Fot. S. Altıer 2017) 


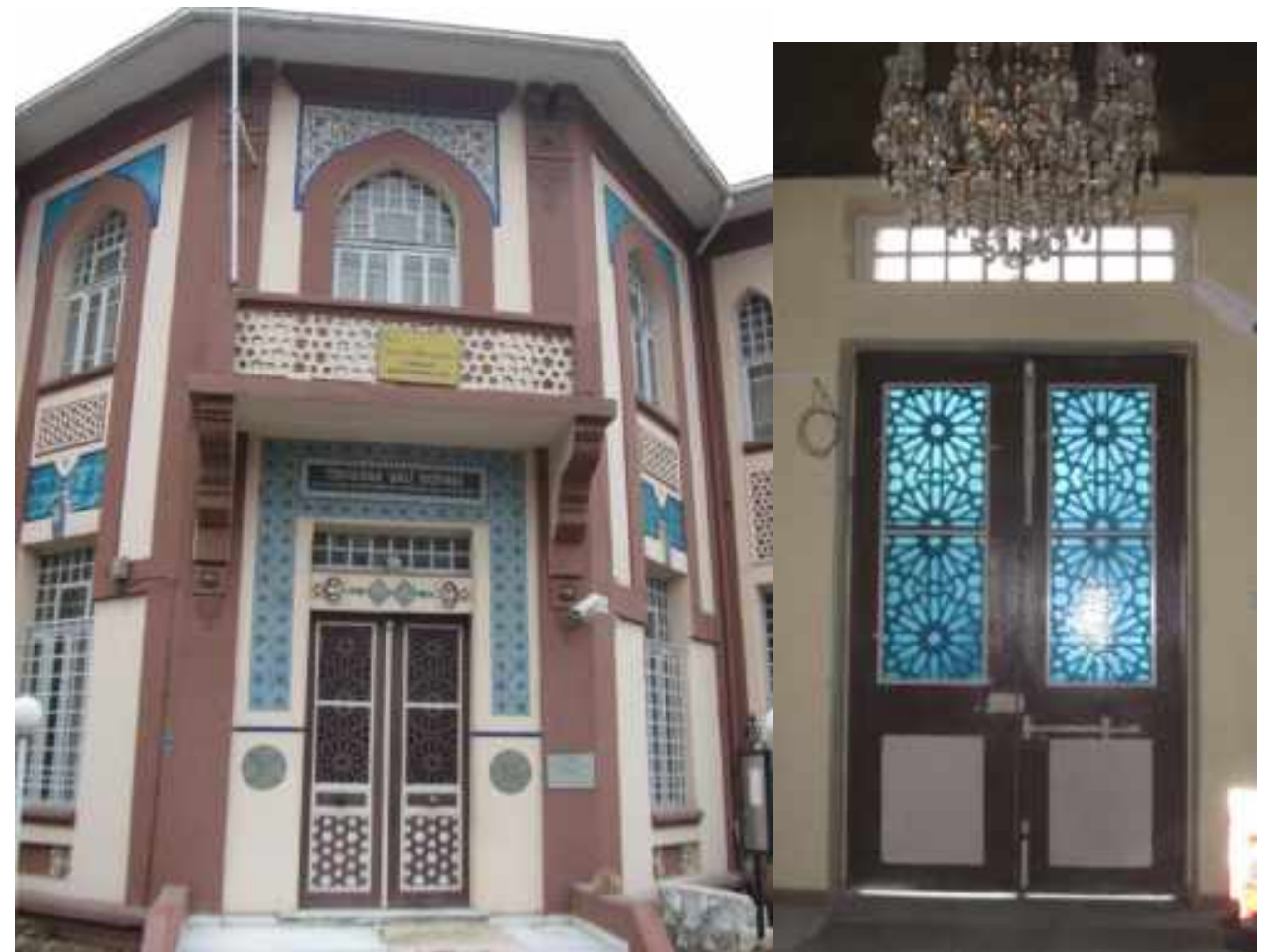

Res. 12a-b. Tekirdağ Eski Vali Konağı, ana kapı dış ve içten görünüm (Fot. S. Altıer 2017)

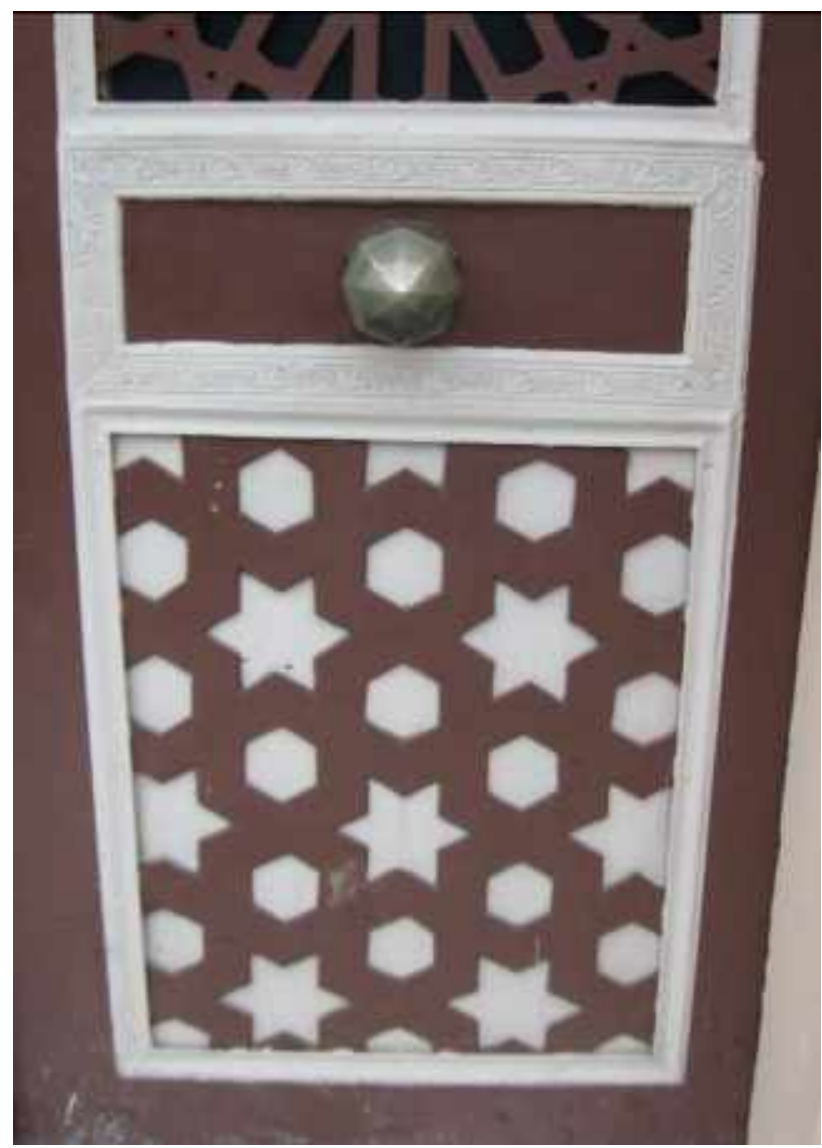

Res. 13. Tekirdağ Eski Vali Konağı, ana kapı süslemeleri (Fot. S. Altıer 2017) 


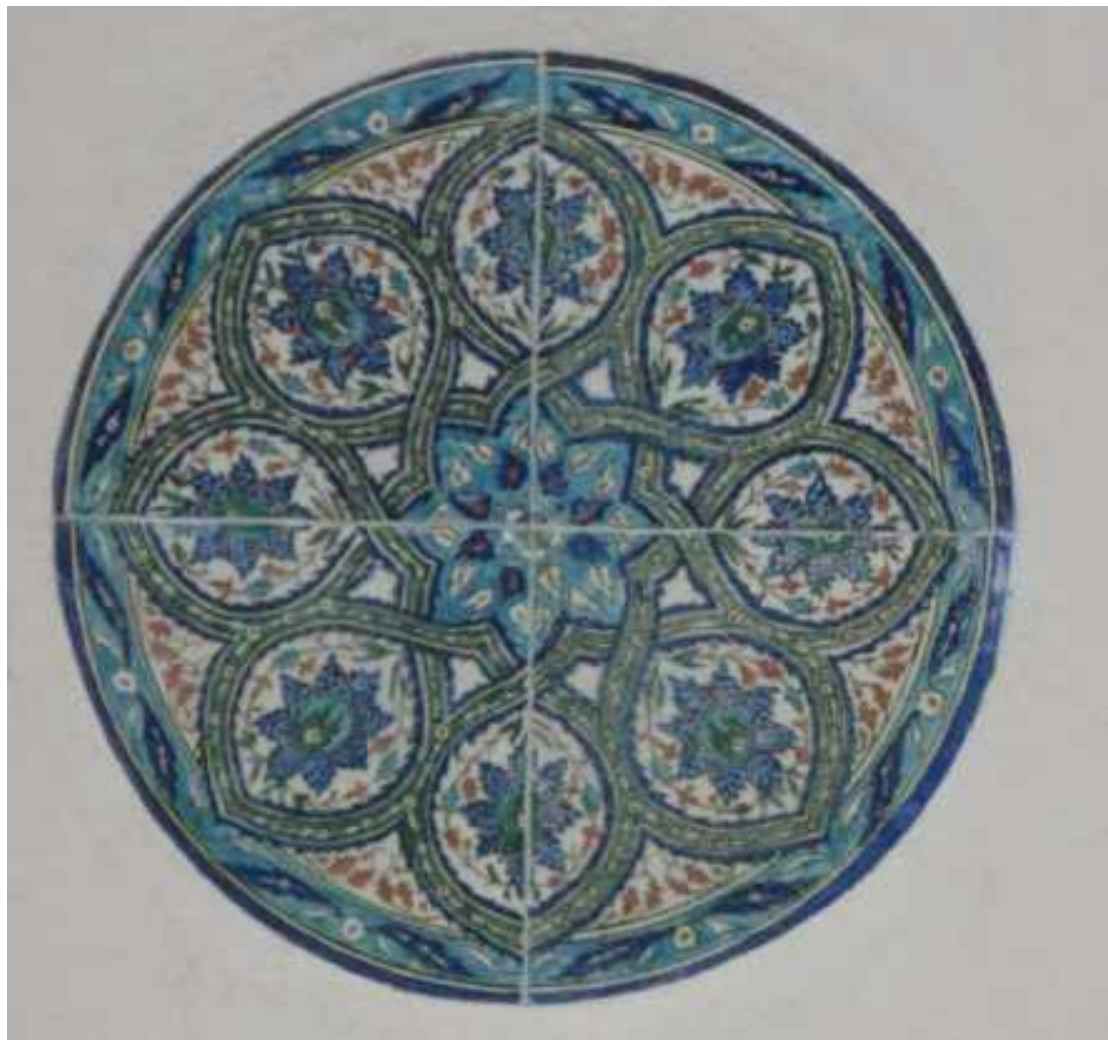

Res. 14. Tekirdağ Eski Vali Konağı, ana kapının iki yanındaki Kütahya çinisi madalyon (Fot. S. Alt1er 2017)

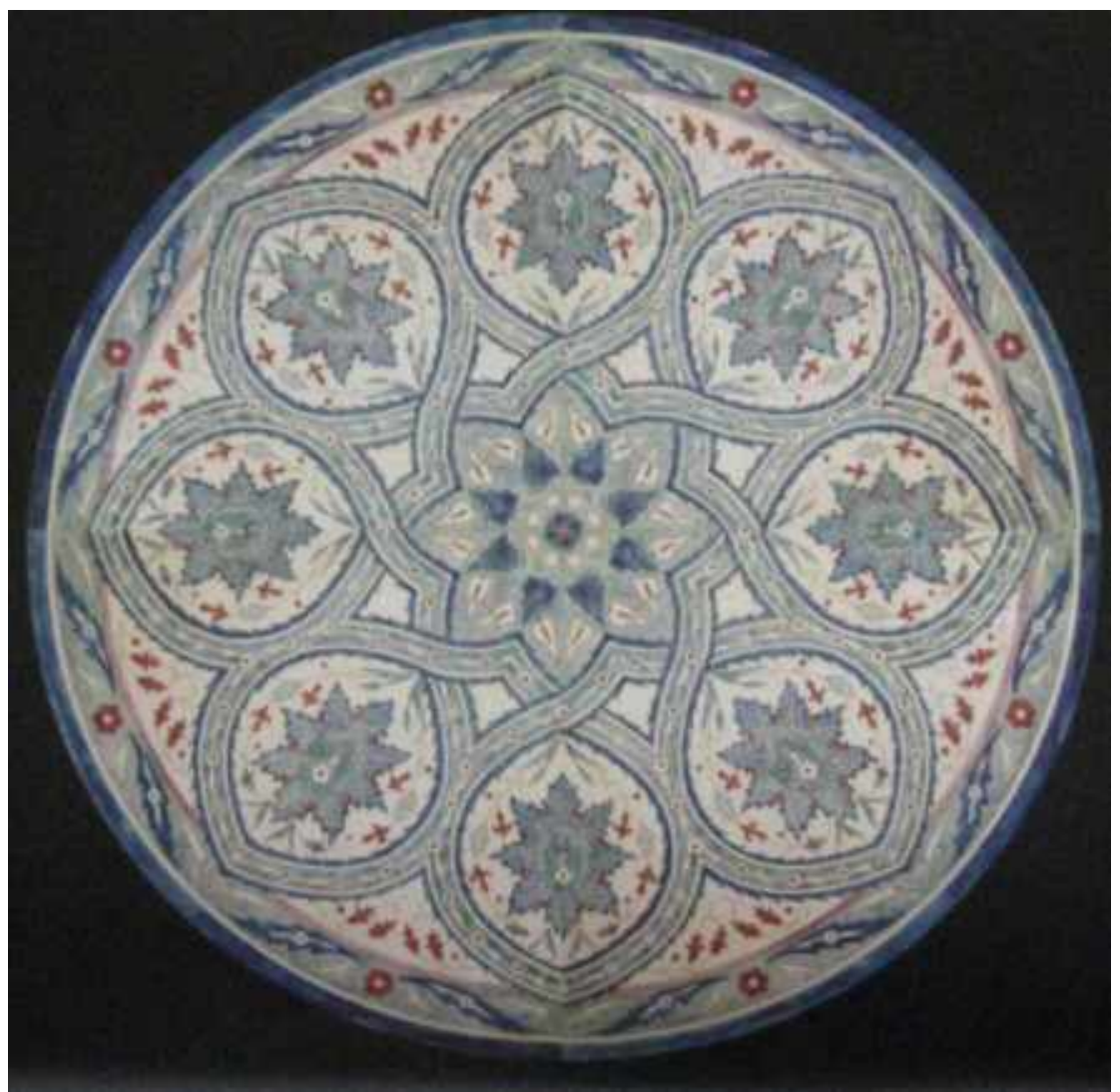

Res. 15. Stepan Vartanyan'a ait çini masa tasarımı (Garo Kürkman 2005, s. 2201). 


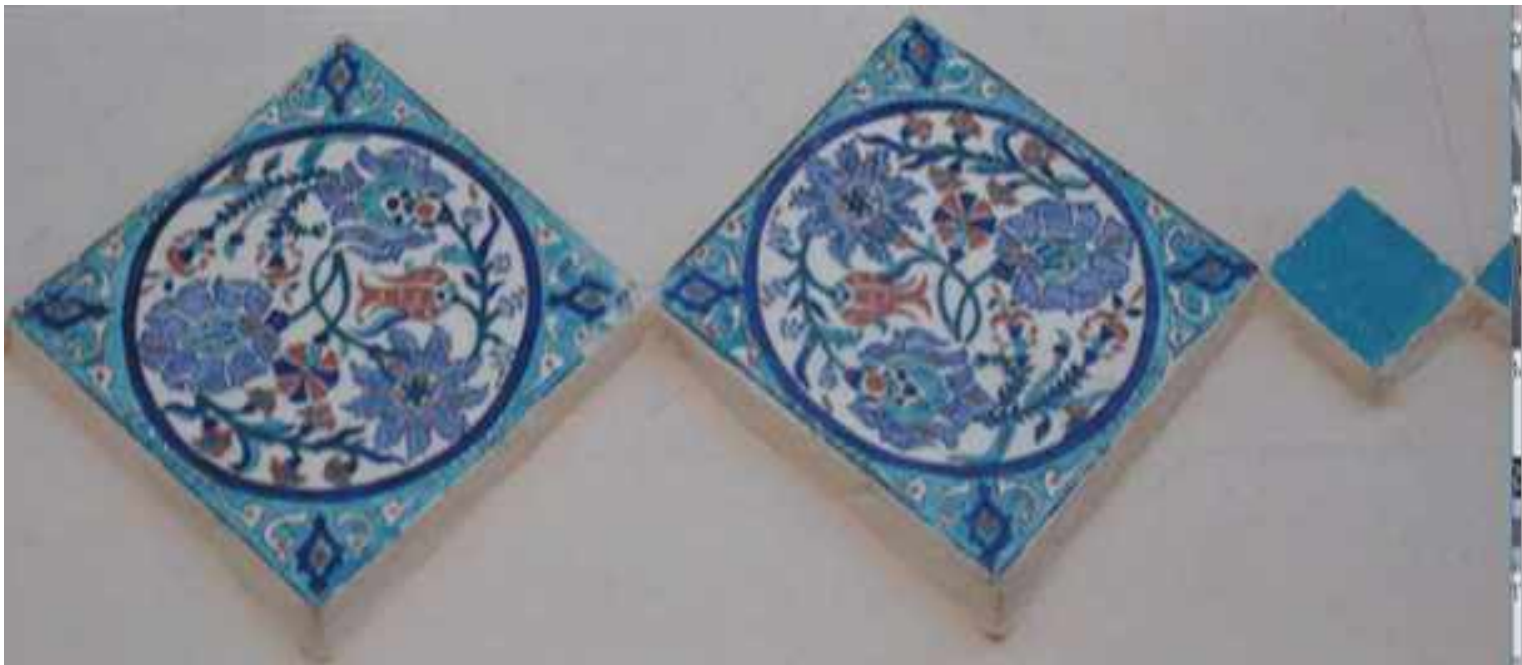

Res. 16. Tekirdağ Eski Vali Konağı, Ana Kapının üzerindeki Kütahya çini panolar (Fot. S. Altier 2017)
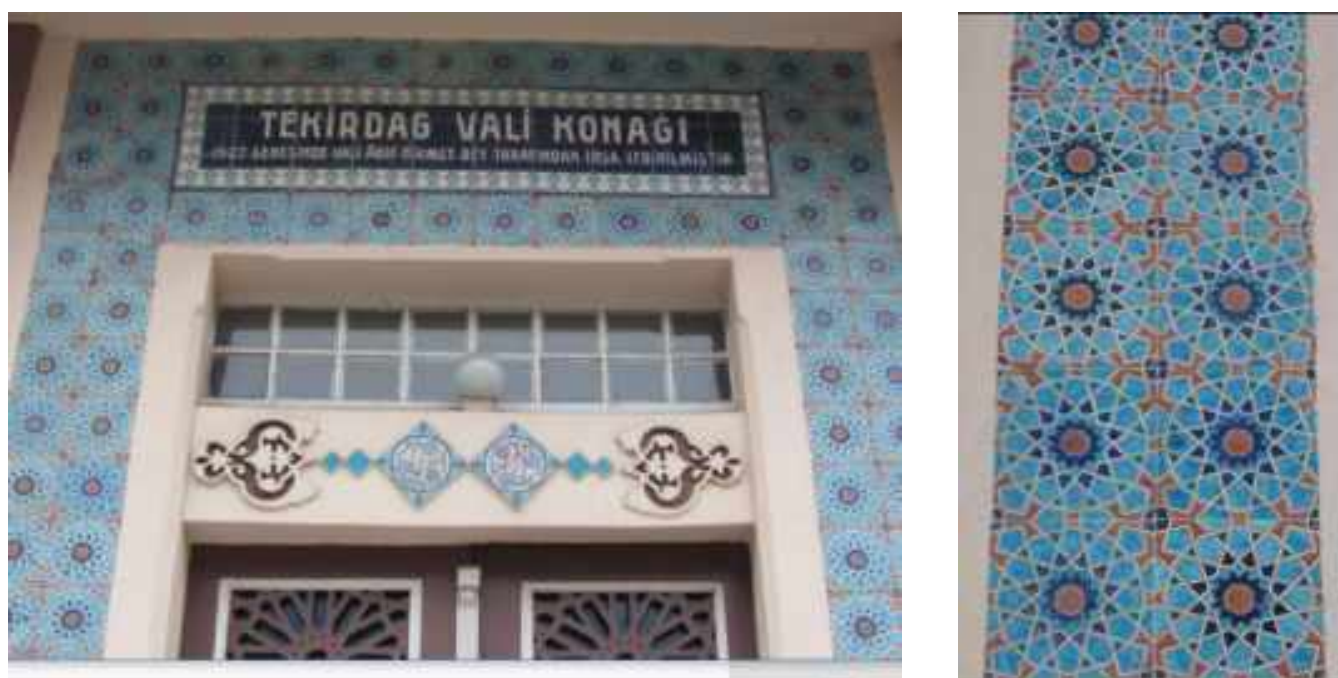

Res. 17a-b. Tekirdağ Eski Vali Konağı, Ana kapıyı dışarıdan kuşatan Kütahya üretimi çiniler (Fot. S. Altier 2017)

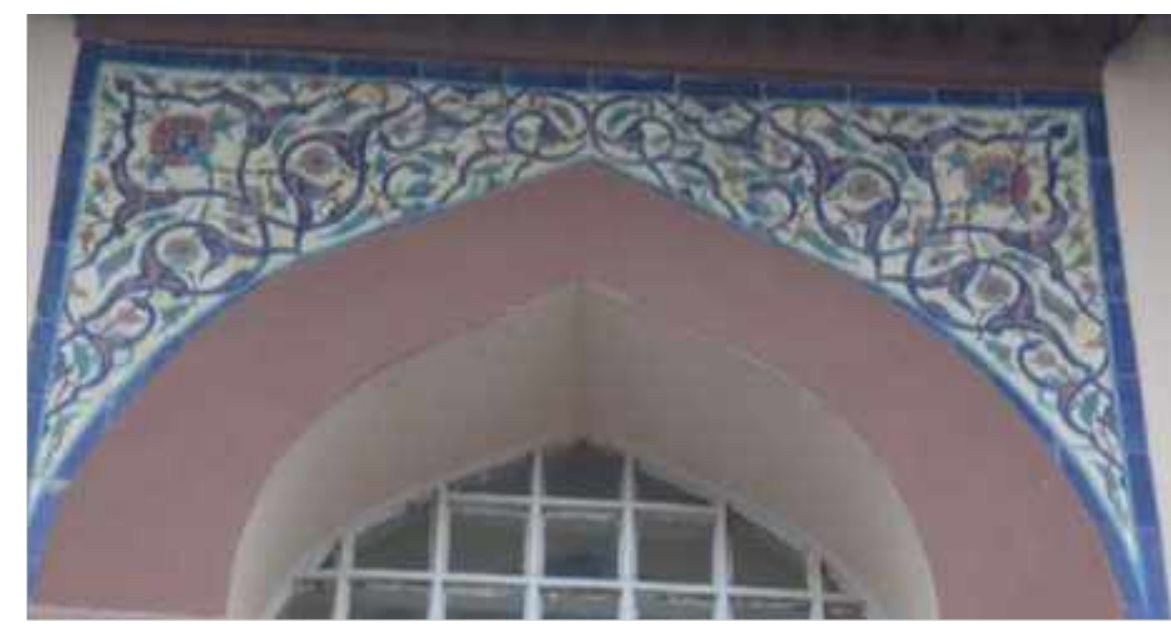

Res. 18. Tekirdağ Eski Vali Konağı, balkon kapısı kemer köşelerinde yer alan Kütahya üretimi çiniler (Fot. S. Altıer 2017) 


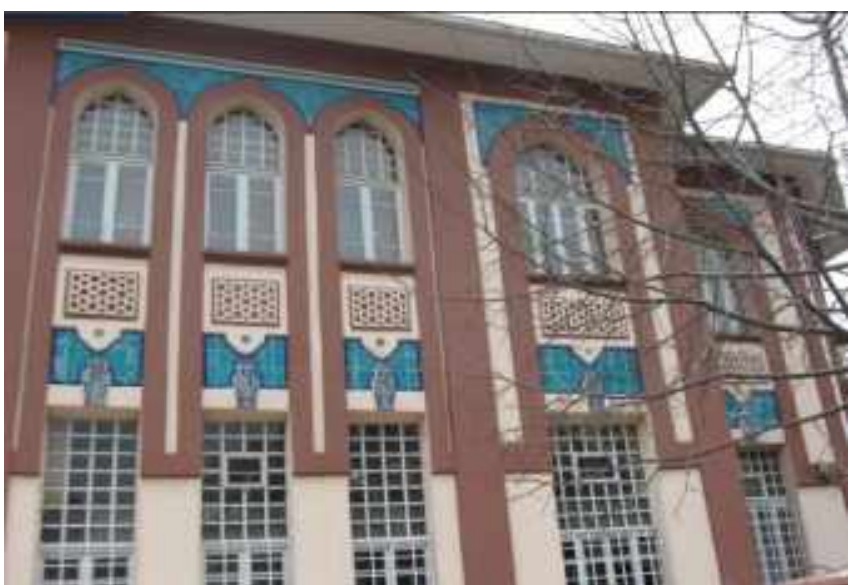

Res. 19. Tekirdağ Eski Vali Konağı, batı cephe Kütahya üretimi çiniler (Fot. S. Altıer 2017)

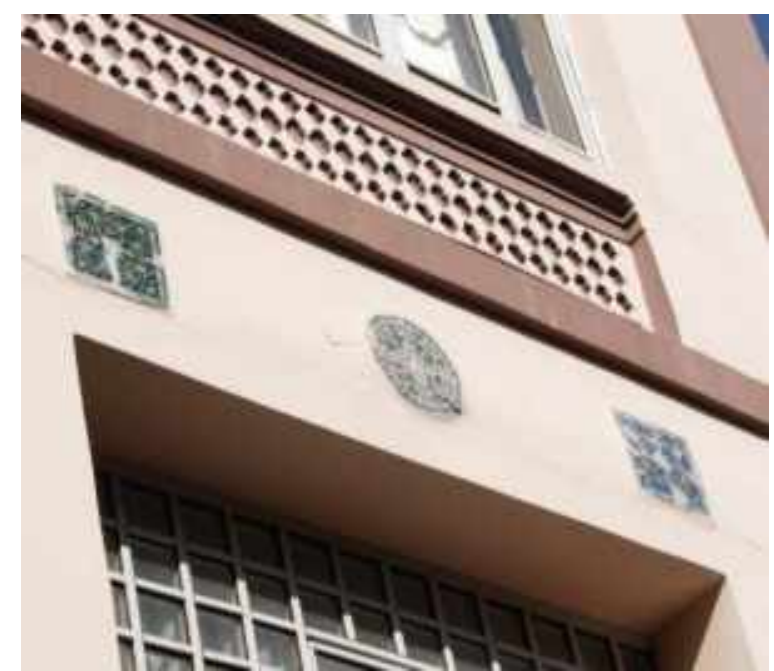

Res. 20. Tekirdağ Eski Vali Konağı, doğu cephe Kütahya üretimi çiniler (Fot. S. Altıer 2017)

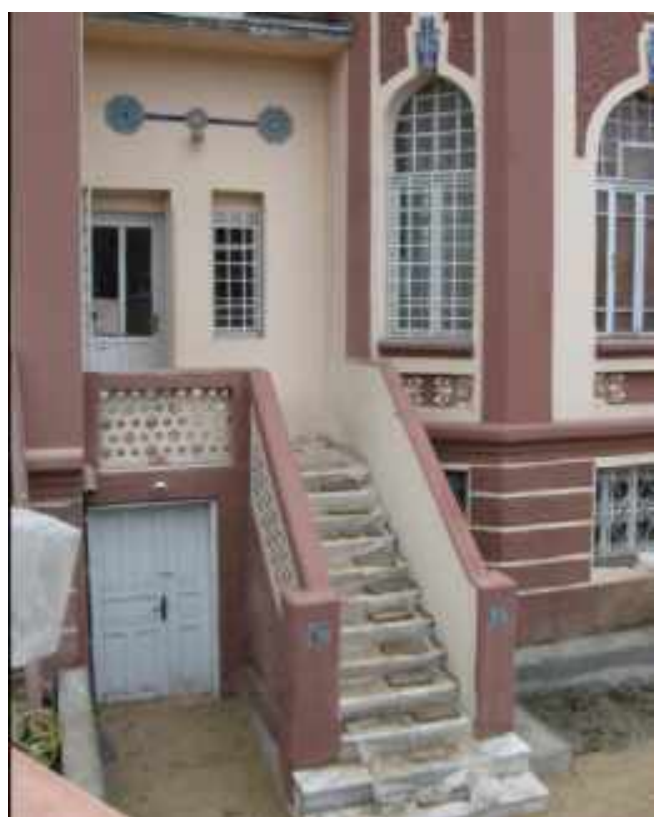

Res. 21. Tekirda ̆̆ Eski Vali Konağı, güney cephe Kütahya üretimi çini panolar ve taş süslemeler (Fot. S. Altıer 2017) 

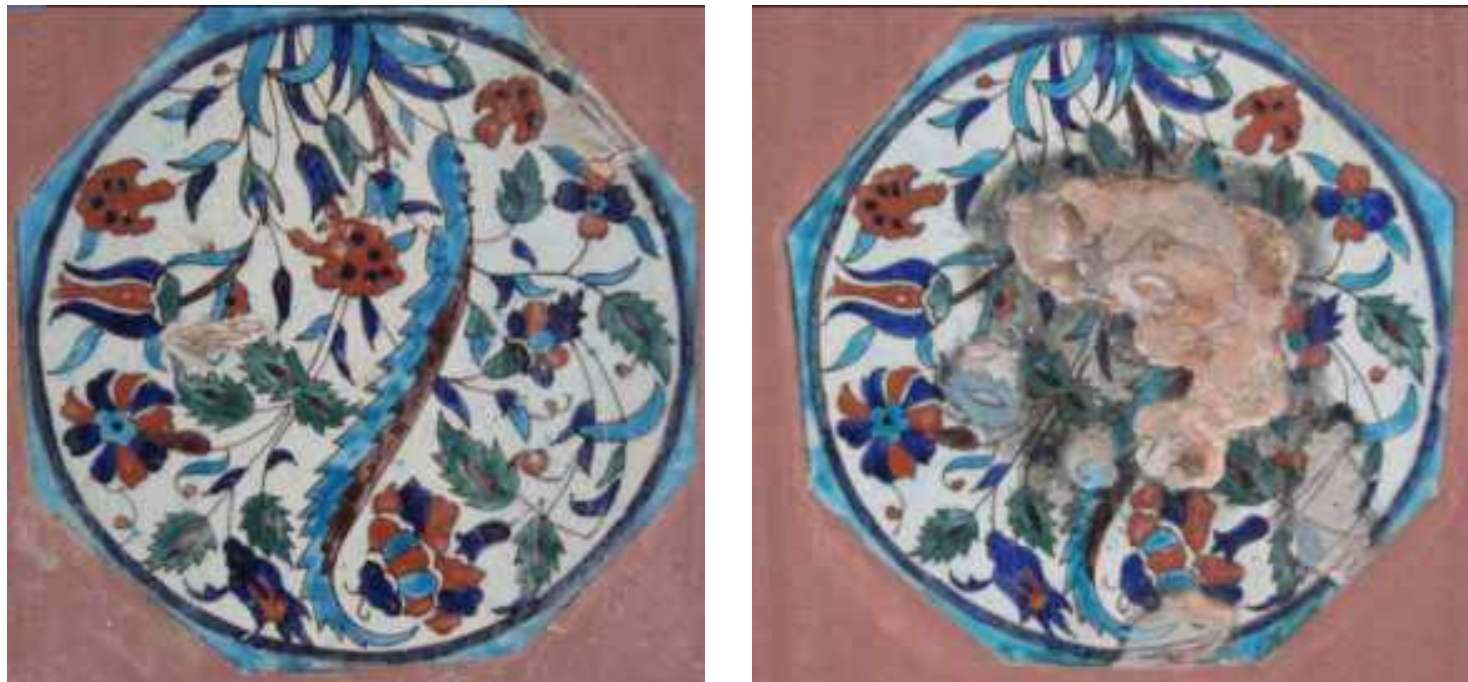

Res 22a. b. Tekirdağ Eski Vali Konağı, güney cephe merdiven başlangıcındaki Kütahya üretimi sekizgen çini panolar
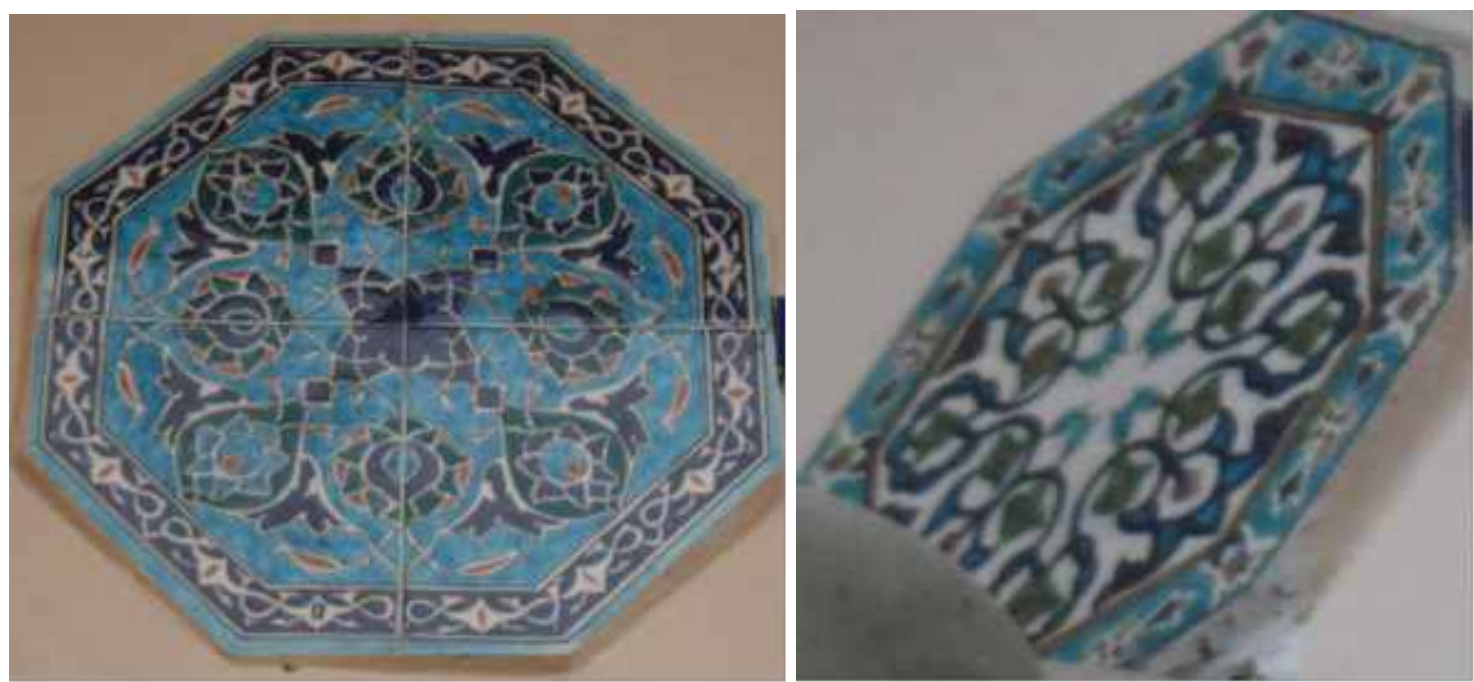

Res 23a. b. Tekirdağ Eski Vali Konağı, güney cephe kapı üzerindeki Kütahya üretimi sekizgen çini panolar 